\title{
ПАЛЕОЗООЛОГИЧЕСКАЯ ХАРАКТЕРИСТИКА ПОЗДНЕНЕОПЛЕЙСТОЦЕН-ГОЛОЦЕНОВЫХ ОТЛОЖЕНИЙ БЫКОВСКОГО ПОЛУОСТРОВА (СЕВЕРНАЯ ЯКУТИЯ)
}

\author{
(C) 2019 г. Т. В. Кузнецова ${ }^{a, b}, *$, В. Е. Тумской ${ }^{a, c, ~ * *, ~}$ \\ Л. Ширрмайстер ${ }^{d, * * *}$, С. Веттерих ${ }^{d, * * * *}$ \\ ${ }^{a}$ Геологический факультет, Московский государственный университет \\ им. М.В. Ломоносова, Москва 119991, Россия \\ ${ }^{b}$ Казанский (Приволжский) Федеральный университет, Казань 420008, Россия \\ ${ }^{c}$ Институт географии РАН, Москва 119017, Россия \\ ${ }^{d}$ Институт им. Альфреда Вегенера, \\ Центр им. Гельмгольца морских и полярных исследований, Потсдам 14473, Германия \\ *e-mail: tatkuz2012@mail.ru \\ **e-mail:vtumskoy@gmail.com \\ ***e-mail: lutz.schirrmeister@awi.de \\ ****e-mail: sebastian.wetterich@awi.de \\ Поступила в редакцию 03.03.2019 г. \\ После доработки 05.06.2019 г. \\ Принята к публикации 06.06.2019 г.
}

\begin{abstract}
Дана палеозоологическая характеристика поздненеоплейстоцен-голоценовых отложений Быковского п-ова (Север Республики Саха - Якутия). Предложена методика разделения ископаемых костных образцов на группы по месту находки и точности привязки к отложениям. Проанализировано 90 радиоуглеродных датировок, полученных в основном по костям крупных млекопитающих. Выявлена неоднородность распределения костного материала по разрезу. Выделено два периода за последние 60 тыс. лет с наиболее благоприятными условиями окружающей среды для обитания крупных представителей мамонтовой фауны. "Холодная" тундростепь с сухим умеренно-теплым или холодным летом - наиболее благоприятные условия жизни мамонтов и копытных млекопитающих на территории современного Быковского п-ова.
\end{abstract}

Ключевые слова: мамонтовая фауна, Быковский полуостров, радиоуглеродные датировки, неоплейстоцен, голоцен, условия окружающей среды, “холодная” тундростепь

DOI: $10.1134 / \mathrm{S} 0044513419110102$

Коренные жители Восточной Сибири с древнейших времен занимались сбором мамонтовых бивней и костей. Задолго до появления русских первопроходцев в этих регионах местные жители добывали и продавали “мамонтовую кость”, т.е. бивни. Да и само освоение и изучение русскими арктических областей Восточной Сибири связано с поиском и добычей мамонтовой кости (Кузнецова, Стародубцева, 2009).

Изучение ископаемых остатков мамонтовой фауны началось с находки мумии мамонта на Быковском п-ове. В 1799 г. охотником Шумаховым был найден труп мамонта, и через семь лет адъюнкт Российской Академии наук М.И. Адамс осмотрел и описал то, что от него осталось. К приезду ученого от туши сохранился лишь скелет и небольшие фрагменты мягких тканей, кожи и шерсти. Скелет этого мамонта, который впо- следствии стали называть мамонтом Адамса, был первым в мире полным скелетом мамонта. Он был смонтирован и выставлен на всеобщее обозрение в 1808 г. в Санкт-Петербурге (Adams, 1808).

Значительно позже, в 1891 г., И.Д. Черским в монументальной работе "Описание коллекции послетретичных млекопитающих животных, собранных Ново-Сибирскою экспедицией 18851886 г.” описано “49 костей, относящихся к 6 видам, - с низовий Лены” (Черский, 1891, с. 69). Вероятно, эти кости были собраны сотрудниками полярной станции, открытой в 1882 г. на о-ве Сагастырь в дельте р. Лена, в числе которых в качестве наблюдателя и врача с момента ее открытия работал А.А. Бунге (1895), ставший впоследствии начальником Ново-Сибирской экспедиции. Публикация И.Д. Черского (1891) содержит не только описание коллекции, но и обобщает все 


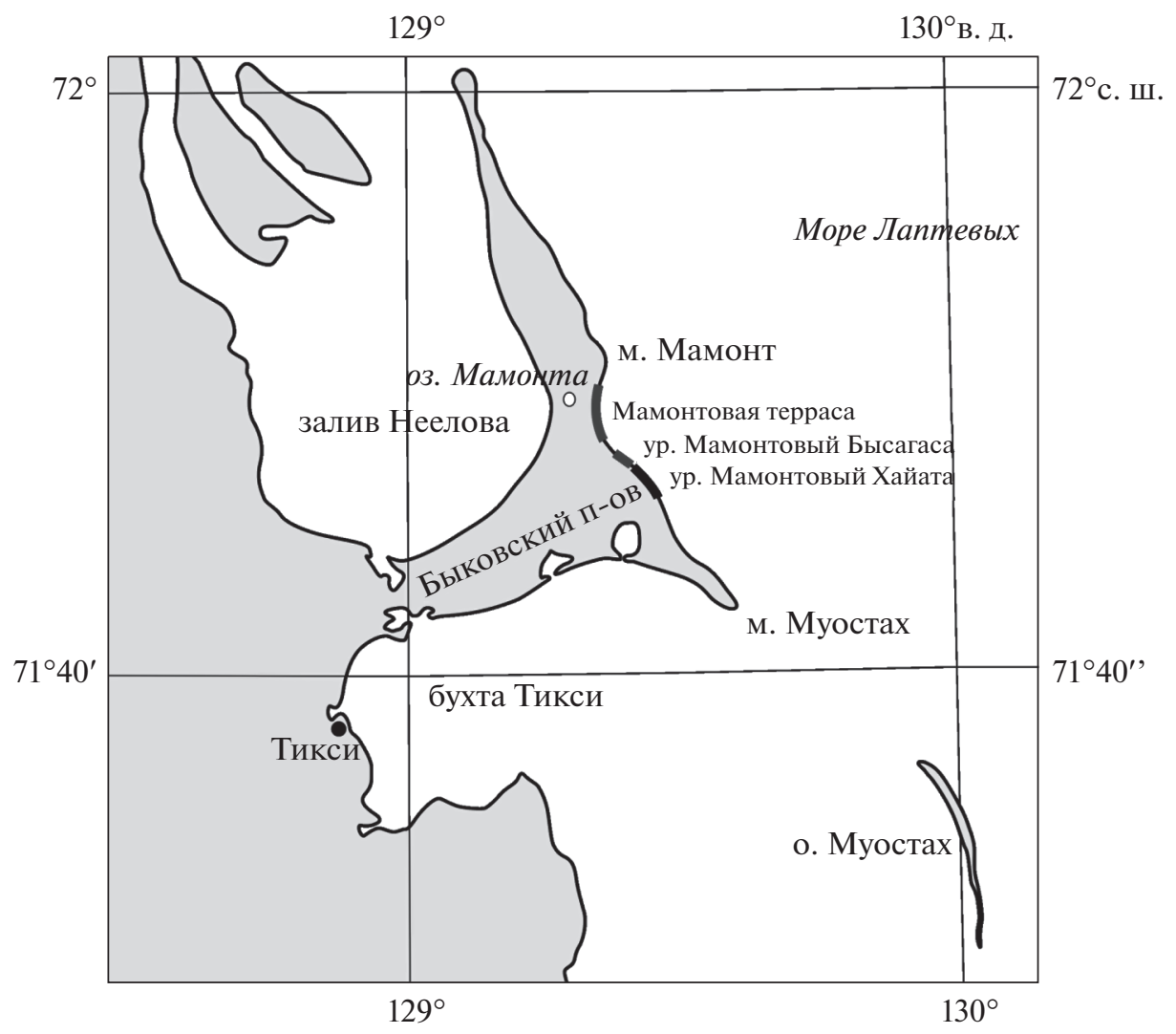

Рис. 1. Карта мест сбора коллекций мамонтовой фауны на Быковском п-ове.

ранее известные материалы по описанию ископаемых млекопитающих Сибири (Кузнецова, Стародубцева, 2009). В конце $20-x-$ начале $30-x$ годов 20 века в районе дельты р. Лены и на Быковском п-ове проводятся работы по геологическому изучению (отряд Якутской экспедиции Академии наук СССР), составлению геологических карт и поисково-исследовательская деятельность (Спижарский, 1937). Палеонтологические находки участников этих экспедиций передавались в музеи. В течение всего 20 века фонды музеев Якутска (Институт геологии алмаза и благородных металлов СО РАН), Санкт-Петербурга (Зоологический институт РАН) и Москвы (Палеонтологический институт им. А. А. Борисяка РАН и Геологический институт РАН) пополнялись образцами, собранными в регионе дельты р. Лена (Кузнецова и др., 2004).

Остатки крупных млекопитающих мамонтовой фауны с Быковского п-ова известны научной общественности более 200 лет, однако планомерного и систематического сбора и изучения палеонтологического материала не производилось. Одной из задач совместной комплексной российско-германской экспедиции по программе "Система моря Лаптевых" было изучение остатков ископаемых млекопитающих четвертичного пе- риода. На Быковском п-ове (рис. 1) комплексное исследование неоплейстоцен-голоценовых отложений в 1998 г. проводилось отрядом под руководством К. Зигерт (Siegert et al., 1999). В 1999 и 2001 гг. обнажение Мамонтовый Хайата изучалось отрядом под руководством А. В. Шера (Sher et al., 2000, 2002), а в 2000 г. - отрядом под руководством Л. Ширрмайстера (Schirrmeister et al., 2001). В результате этих комплексных экспедиций была собрана уникальная по полноте палеонтологическая коллекция крупных млекопитающих мамонтовой фауны, большая часть которой хранится в Палеонтологическом институте РАН.

Одной из задач данной статьи было введение в научное обсуждение данных, полученных в результате как непосредственно экспедиционных работ российско-немецкого научного коллектива, работавшего по программе "Система моря Лаптевых”, так и некоторых аналитических наработок нашей группы.

\section{МАТЕРИАЛ И МЕТОДИКА Сбор материала}

Для всеобъемлющего и разностороннего исследования палеозоологического материала собирали и определяли все остатки млекопитаю- 
Таблица 1. Коллекция остатков млекопитающих и птиц, собранная на Быковском п-ове

\begin{tabular}{|c|c|c|c|c|c|c|c|c|}
\hline \multirow{2}{*}{ Семейство } & & \multirow{2}{*}{ Всего } & \multicolumn{3}{|c|}{ Мамонтовый Хайата } & \multirow{2}{*}{$\begin{array}{c}\text { Мамонтовая } \\
\text { терраса }\end{array}$} & \multirow{2}{*}{$\begin{array}{c}\text { Мыс } \\
\text { Мамонта }\end{array}$} & \multirow{2}{*}{ Другие } \\
\hline & & & Разрез & Берег и отмель & Всего & & & \\
\hline Elephantidae & $\begin{array}{l}\text { Mammuthus primigenius } \\
\text { (Blumenbach 1799) }\end{array}$ & 419 & 75 & 273 & 348 & 45 & 20 & 6 \\
\hline \multirow[b]{2}{*}{ Bovidae } & Bison priscus (Bojanus 1827) & 148 & 10 & 76 & 86 & 33 & 24 & 5 \\
\hline & $\begin{array}{l}\text { Ovibos moschatus } \\
\text { (Zimmermann 1780) }\end{array}$ & 21 & 3 & 16 & 19 & 1 & 1 & \\
\hline \multirow{2}{*}{ Cervidae } & Rangifer tarandus L. 1758 & 164 & 36 & 86 & 122 & 28 & 7 & 7 \\
\hline & Alces alces (L. 1758) & 3 & 1 & 1 & 2 & 1 & & \\
\hline Equidae & Equus ex eg. caballus L. 1758 & 269 & 29 & 186 & 215 & 42 & 10 & 2 \\
\hline Felidae & $\begin{array}{l}\text { Panthera spelaea } \\
\text { (Goldfuss 1810) }\end{array}$ & 2 & & & & 2 & & \\
\hline \multirow[t]{2}{*}{ Canidae } & Canis sp. & 3 & & 3 & 3 & & & \\
\hline & Другие хищные & 5 & & 2 & 2 & 1 & & 2 \\
\hline \multirow[t]{5}{*}{ Leporidae } & Lepus sp. & 82 & 34 & 43 & 77 & 2 & & 3 \\
\hline & Птицы & 5 & 3 & 1 & 4 & 1 & & \\
\hline & Другие & 15 & & 9 & 9 & 6 & & \\
\hline & Неопределенные & 55 & 18 & 25 & 43 & 10 & & 2 \\
\hline & Всего & 1191 & 209 & 721 & 930 & 172 & 62 & 27 \\
\hline
\end{tabular}

щих различной сохранности, включая мелкие фрагменты костей. Это позволило наиболее полно восстановить процентное соотношение основных видов крупных млекопитающих мамонтовой фауны, обитавших на данной территории.

Используя в качестве сравнительного материала коллекцию отдела остеологии Зоологического музея МГУ, подавляющее большинство находок определяли до вида. Таким образом, были охарактеризованы неоплейстоценовые отложения Быковского п-ова и о-ва Муостах. Общее количество собранных костных остатков - около 1200 образцов (табл. 1).

Для сбора грызунов 22 пробы из разреза промывали in situ. Каждая проба представляла собой 30-40 кг породы, которая промывалась на сите с диаметром ячейки 1 мм. В качестве дополнительного материала первым автором изучены коллекции из этого же региона, хранящиеся в Зоологическом, Палеонтологическом им. А.А. Борисяка и Геологическом институтах РАН, Институте геологии алмаза и благородных металлов СО РАН (Якутск), а также в музее Усть-Ленского заповедника (п. Тикси).

Основной задачей при сборе собственного материала являлась фиксация места находки каждого образца. Каждый образец маркировали сразу же при находке и относили к той или иной груп- пе. По точности привязки к обнажению образцы разделили на несколько групп.

В группу “a” входят образцы, найденные в слое в мерзлом состоянии, т.e. in situ. Это образцы, для которых известны место и высота отбора в разрезе. К этой группе относится наименьшее число образцов, что связано со спецификой сбора материала в зоне развития многолетнемерзлых отложений этого региона. Работы экспедиции велись в зоне развития отложений ледового комплекса, в состав которых входит до $85 \%$ ископаемого льда. В летний период происходит интенсивное таяние ледового комплекса, что приводит к сползанию оттаявшей водно-минеральной массы к основанию разреза.

Группа “b” объединяет образцы, для которых можно определить интервал залегания, т.е. можно выделить так называемое “костное поле”. Образцы, относящиеся к этой группе, были найдены не в мерзлом, а уже в вытаявшем состоянии. Однако мы можем восстановить верхнюю и нижнюю границу их возможного залегания в разрезе.

Группа “с" состоит из образцов, собранных в осыпи на разрезе.

Группа "d" - это кости, собранные не на разрезах, а на берегу под разрезами или на отмели. К этой группе относится самое большое количе- 
ство костей и их фрагментов. Остальные группы, выделенные нами, объединяют находки из различных других мест. Например, группа "e" включает кости, собранные на берегу, но не под изучаемыми разрезами и т.д. (Siegert et al., 1999).

Весь костный материал по сохранности разделяли на шесть групп. Четких границ между этими группами нет. В коллекции встречаются кости, которые по своей сохранности занимают переходное положение между группами и которые могут быть весьма условно отнесены к той или иной группе.

Группа 1. Включает костный материал наилучшей сохранности. Цвет кости с поверхности белый или слабо желтоватый. Кости гладкие, некоторые глянцевые. Свежий скол белый. Кости, относящиеся к этой группе, часто легкие, т.е. практически не фоссилизованы. К этой группе относится костный материал (например, кости мамонтов) с разреза (группы a, b, c), которые при захоронении сразу же были погребены осадками и не испытывали процессов переноса, переотложения или длительного выветривания. К этой же группе относятся кости группы d, которые недавно вытаяли из отложений ледового комплекса. Однако к этой же группе отнесены кости и современных северных оленей.

Группа 2. Цвет с поверхности кости светложелтый, суставные поверхности могут быть прокрашены интенсивнее и могут иметь более темный оттенок. Кости гладкие, глянцевые. На старом сломе - желтоватые, на свежем сломе - однородно белые, без зон прокрашивания. Эту группу составляют кости с разреза, которые, по-видимому, при захоронении в течение короткого времени были погребены осадками и не испытывали процессов переноса, переотложения или длительного выветривания.

Группа 3. Цвет с поверхности кости желтокрасный. Окраска неоднородная, на различных частях кости присутствуют все переходы от желтого к желто-красному и коричнево-красному. Кости гладкие, глянцевые. На старом сломе кремоватые. На свежем сколе кости белые, иногда светло-кремовые, отмечается очень тоненькая корочка более темного цвета с поверхности кости. Есть кости гладкие до блеска, бивни и щечные зубы не выветрелые с поверхности. Наиболее разнообразная группа со всевозможными переходами окраски (в пределах описанной) как поверхности кости, так и старых сломов и свежих спилов.

Группа 4. Цвет с поверхности кости темнокрасный, суставные поверхности прокрашены интенсивнее (более темные). Кости гладкие, глянцевые. Бивни гладкие, не выветрелые с поверхности, щечные зубы - темно-красные, почти черные. На старом сломе кости темно-желтые, светло-коричневые и красные. На свежем сколе грязно-белые, с хорошо заметным светло-коричневым ободком по поверхности или светло-кремовые без ободка.

Группа 5. Цвет с поверхности кости красный, темно-красный, иногда почти черный. Кости выветрелые с поверхности, но не очень сильно, растрескавшиеся. Поверхность гладкая, хотя и разбита крупными трещинами. На старом сломе кости темно-бежевые, темно-коричневые, иногда видны пятна прокраски и зоны более темные и более светлые.

Группа 6. Цвет с поверхности кости буроватосерый, поверхность рыхлая, не гладкая, шелушащаяся. Кости выветрелые с поверхности, некоторые окатанные. Обломки бивней все растрескавшиеся. На старом сломе кости буро-красные, с зонами и пятнами неоднородной прокраски. К этой группе также относятся растрескавшиеся рога оленей. Группа объединяет костный материал наихудшей сохранности. Кости, вероятно, длительное время подвергались выветриванию либо до захоронения в осадках, либо уже после вытаивания. Кроме окатанных костей, к этой группе относятся кости, истертые льдом. Такая специфическая форма сохранности характерная только для материала, собранного с берега или косы.

\section{Радиоуглеродное датирование костного материала}

В результате массового датирования костных остатков млекопитающих создали базу данных радиоуглеродных дат по поздненеоплейстоценголоценовым представителям мамонтовой фауны Быковского п-ова. База содержит 90 дат: 88 дат с Быковского п-ова и 2 даты с о-ва Муостах (табл. 2). Уникальность этой базы данных в том, что для многих дат известно место отбора образца в разрезе. В качестве дополнительного материала использовали ранее опубликованные данные с п-ова Таймыр (Сулержицкий, 1995; Сулержицкий, Романенко, 1997).

Определение радиоуглеродного возраста костей проводили в основном конвенционным методом, который предполагает навеску материала для исследования около 1 кг. Для такого метода определения абсолютного возраста отбирали крупные кости конечностей или их фрагменты. Благодаря хорошей сохранности материала в мерзлых породах этим методом удавалось получить даты и для более мелких образцов (например, фрагменты костей конечности лошади, рогов северного оленя и др.). Основное количество датировок получили в лаборатории Геохимии изотопов и геохронологии Геологического института РАН (Москва). Следует особо отметить, что для датировок строго использовали только 


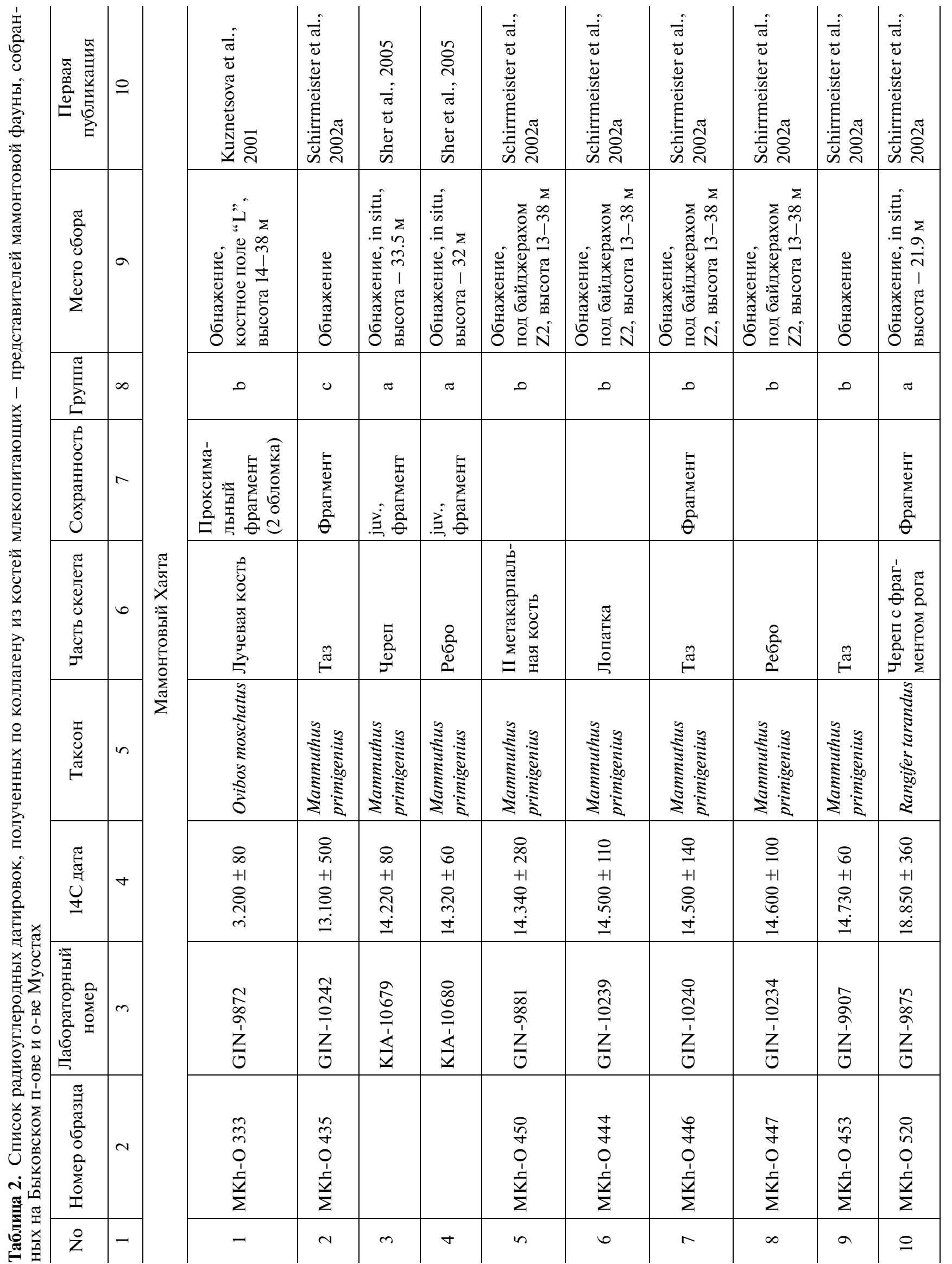




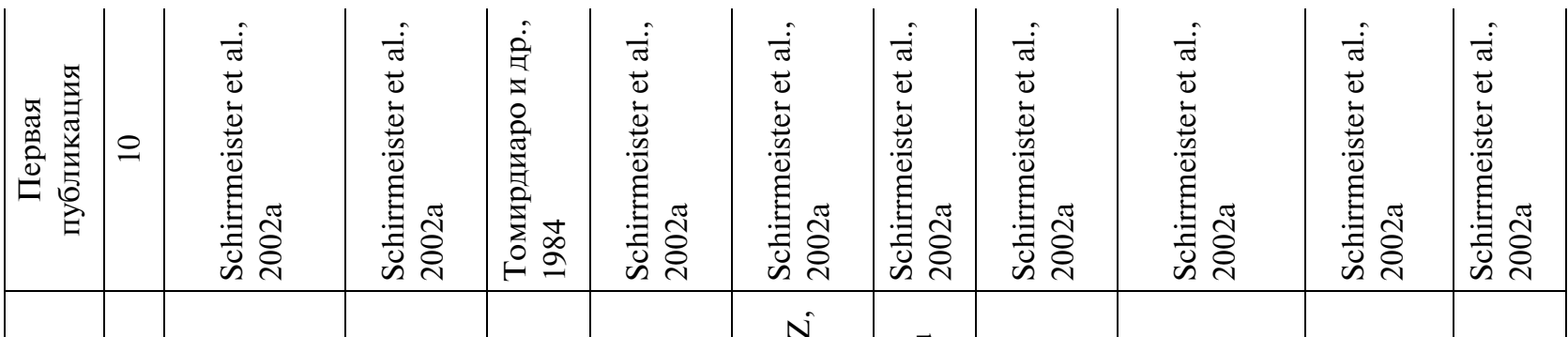

\begin{tabular}{|c|c|c|c|c|c|c|c|c|c|c|}
\hline 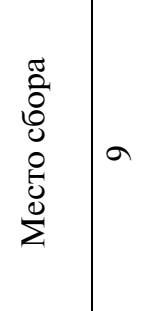 & 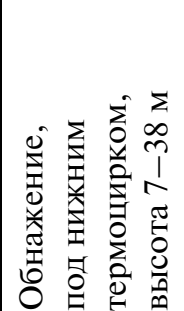 & 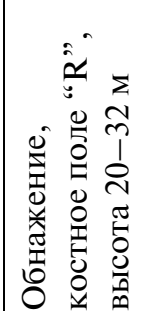 & 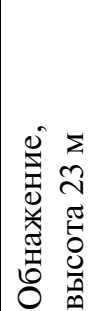 & 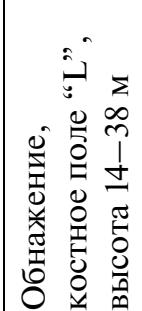 & 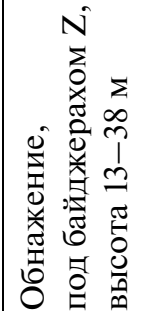 & 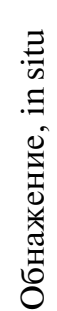 & 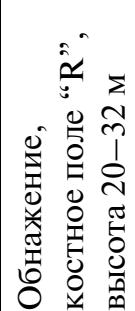 & 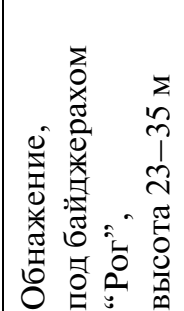 & 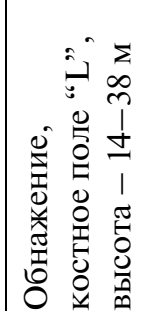 & 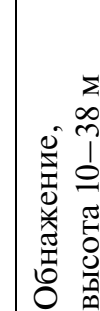 \\
\hline$\infty$ & م & 0 & & مـ & مـ & $\pi$ & م & م & 气 & \\
\hline
\end{tabular}

\begin{tabular}{|c|c|c|c|c|c|c|c|c|c|}
\hline 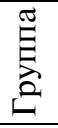 & $\infty$ & م & م & 0 & م & $\pi$ & م & م & م \\
\hline$\stackrel{\Omega}{\theta}$ & & & & & & & & & \\
\hline
\end{tabular}

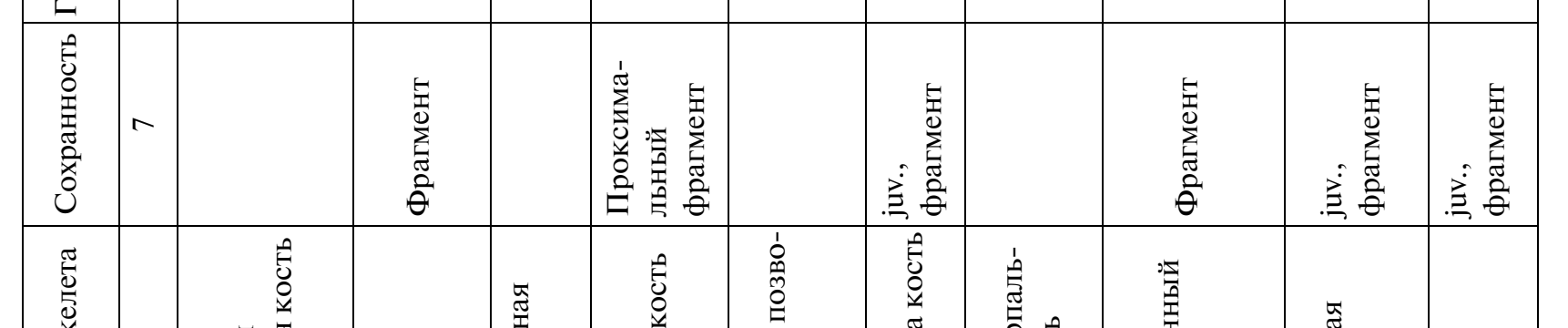

\begin{tabular}{|c|c|c|c|c|c|c|c|c|c|c|}
\hline 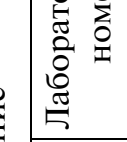 & $m$ & 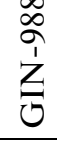 & $\begin{array}{l}0 \\
\frac{1}{1} \\
\frac{1}{3}\end{array}$ & 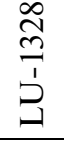 & $\frac{a}{i}$ & $\begin{array}{l}\frac{0}{1} \\
\frac{1}{3} \\
0\end{array}$ & $\begin{array}{l}\infty \\
\infty \\
i \\
z \\
0\end{array}$ & $\begin{array}{l}\infty \\
\infty \\
i \\
z \\
\vdots \\
0\end{array}$ & $\begin{array}{l}\infty \\
\infty \\
\grave{1} \\
\vdots\end{array}$ & $\begin{array}{l}\infty \\
\substack{\infty \\
\vdots}\end{array}$ \\
\hline 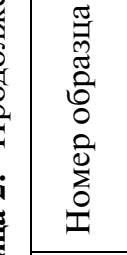 & $\sim$ & $\begin{array}{l}0 \\
0 \\
0 \\
1 \\
1 \\
\frac{1}{2} \\
\Sigma\end{array}$ & 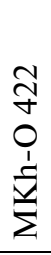 & & $\begin{array}{l}\text { N } \\
\text { On } \\
0 \\
1 \\
\vdots \\
\Sigma \\
\Sigma\end{array}$ & $\begin{array}{l}\vec{\infty} \\
\infty \\
0 \\
1 \\
\dot{v} \\
\Sigma\end{array}$ & $\begin{array}{l}\hat{0} \\
0 \\
0 \\
1 \\
\dot{1} \\
\Sigma \\
\Sigma\end{array}$ & $\begin{array}{l}a \\
i n \\
0 \\
1 \\
\frac{1}{2} \\
\Sigma \\
\Sigma\end{array}$ & $\begin{array}{l}+ \\
\infty \\
0 \\
0 \\
1 \\
\dot{1} \\
\Sigma \\
\Sigma\end{array}$ & $\begin{array}{l}\text { సे } \\
0 \\
1 \\
\frac{1}{2} \\
\Sigma\end{array}$ \\
\hline 之 & - & $=$ & $\simeq$ & $\underline{n}$ & $\Xi$ & 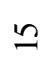 & 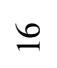 & $=$ & 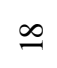 & $\stackrel{2}{ }$ \\
\hline
\end{tabular}




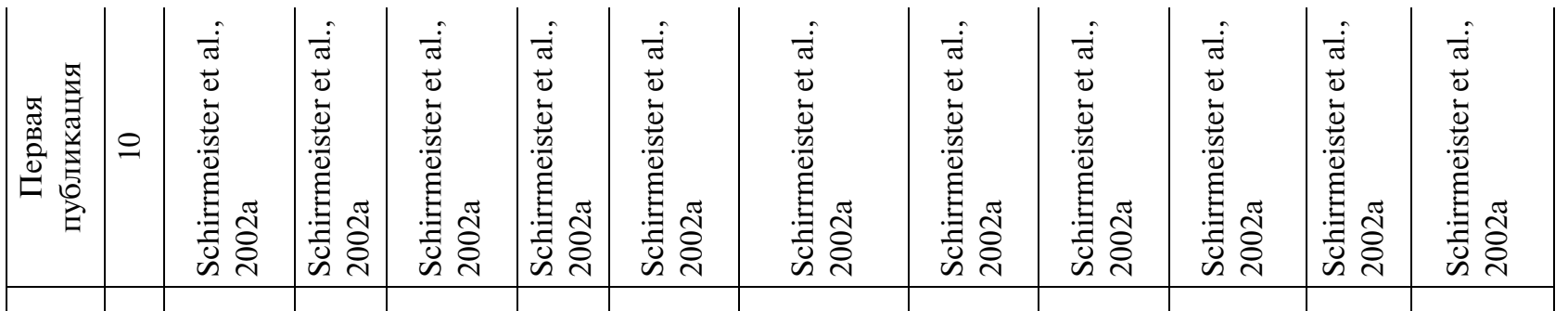

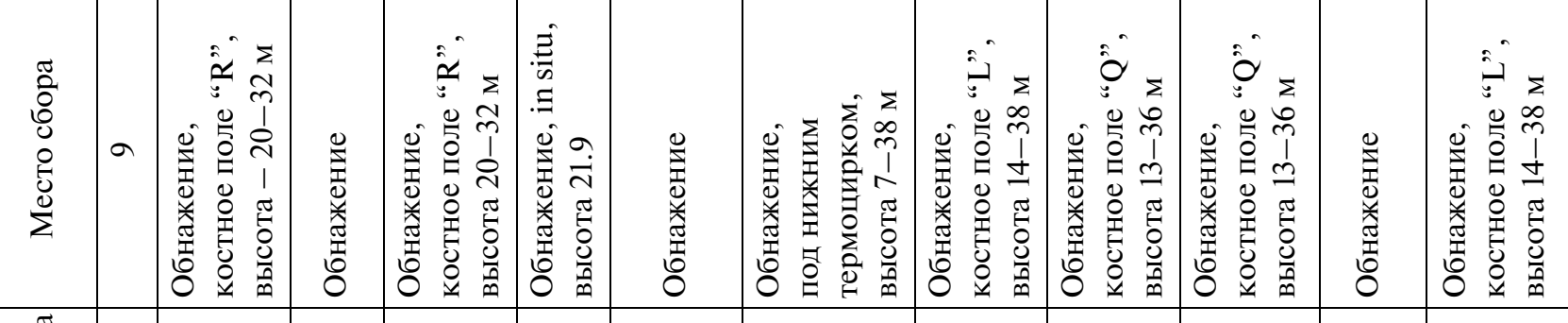

\begin{tabular}{|c|c|c|c|c|c|c|c|c|c|c|c|c|}
\hline$\stackrel{\widetilde{G}}{\mathrm{~B}}$ & $\infty$ & م & 0 & م & $\pi$ & 0 & م & م & م & م & 0 & 0 \\
\hline
\end{tabular}

\begin{tabular}{|c|c|c|c|c|c|c|c|c|c|c|c|c|}
\hline 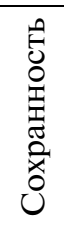 & $r$ & 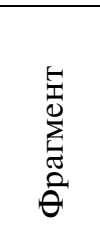 & 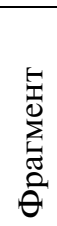 & & 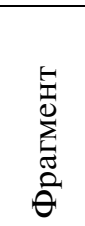 & 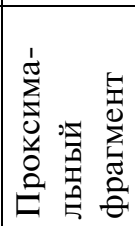 & 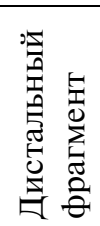 & & & & 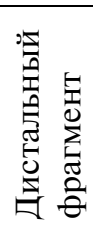 & \\
\hline 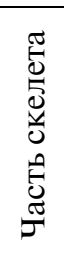 & 6 & 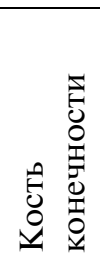 & $\stackrel{\tilde{\mathscr{E}}}{\leftarrow}$ & $\begin{array}{l}\text { : } \\
\text { o } \\
\text { 2. }\end{array}$ & 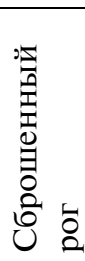 & 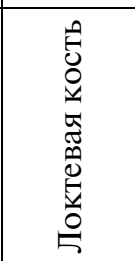 & 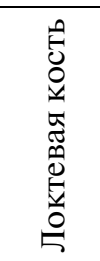 & 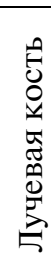 & 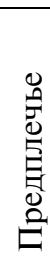 & 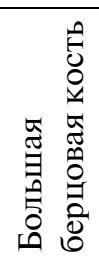 & 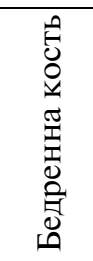 & 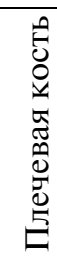 \\
\hline
\end{tabular}

\begin{tabular}{|c|c|c|c|c|c|c|c|c|c|c|c|}
\hline $\begin{array}{l}\text { T. } \\
\text {. } \\
\text { a }\end{array}$ & 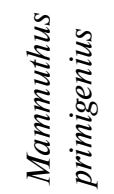 & 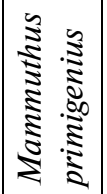 & 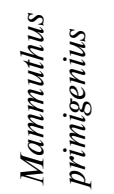 & 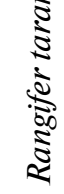 & 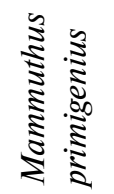 & 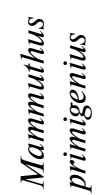 & 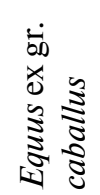 & 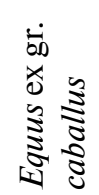 & $\begin{array}{r}5 \\
0 \\
0 \\
0 \\
0 \\
0 \\
0 \\
0\end{array}$ & 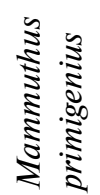 & 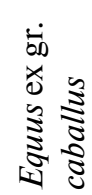 \\
\hline & $£$ & 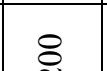 & $\S$ & 8 & $\varepsilon$ & 8 & & $\subsetneq$ & 8 & 8 & \\
\hline
\end{tabular}

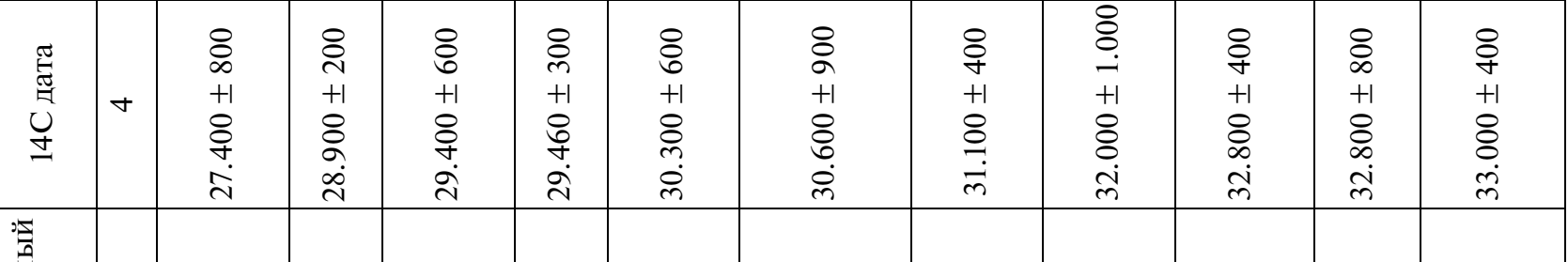

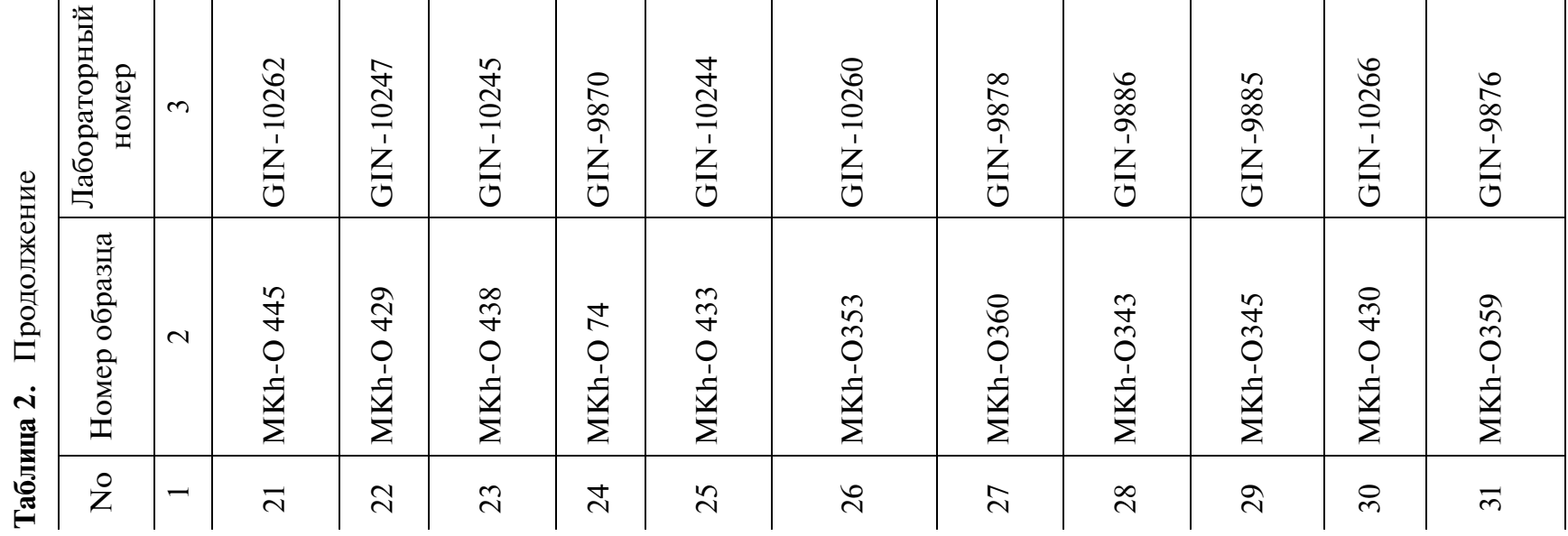




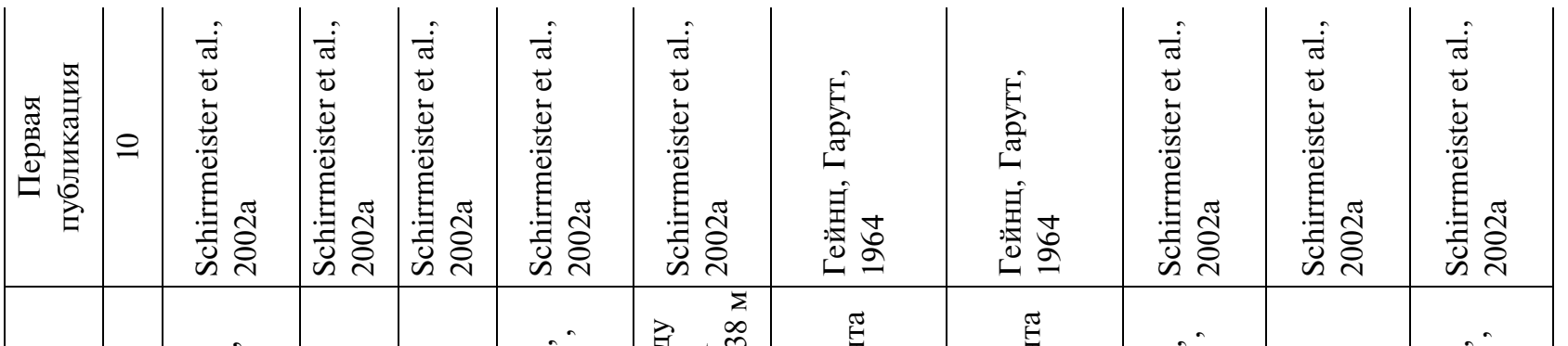

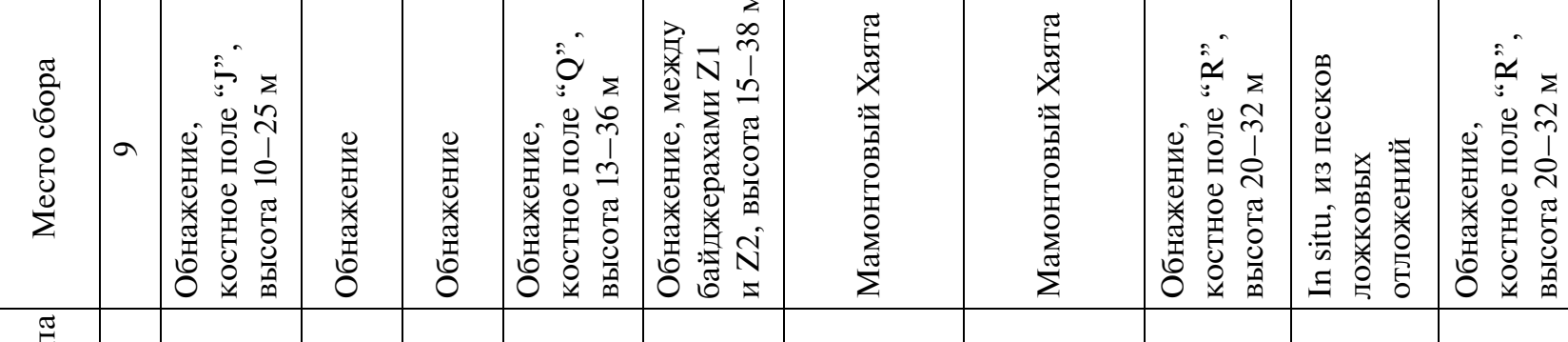

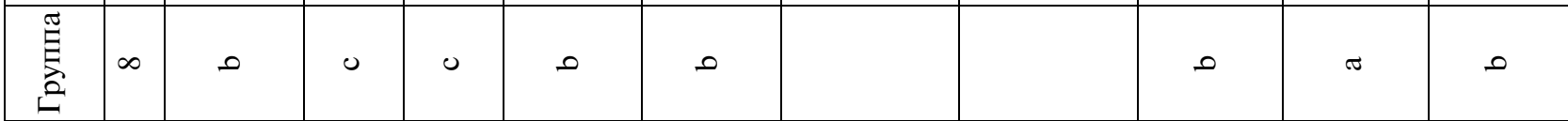

\begin{tabular}{|c|c|c|c|c|c|c|c|c|c|c|c|}
\hline 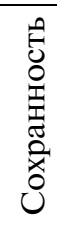 & $n$ & 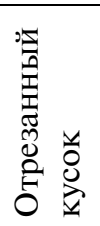 & 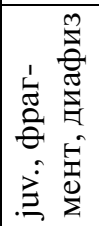 & 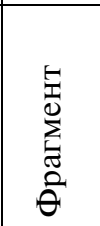 & & 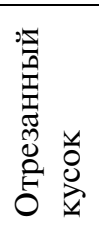 & & & 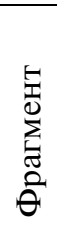 & 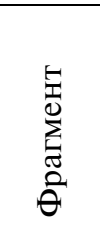 & $\begin{array}{l}\underbrace{0}_{0} \\
\sum_{\overline{0}}^{0} \\
\hat{\theta}\end{array}$ \\
\hline 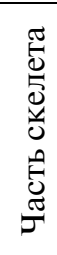 & 6 & 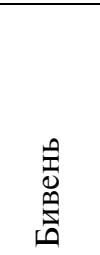 & 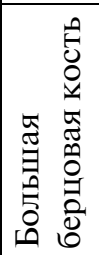 & 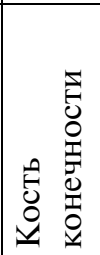 & 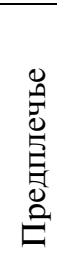 & 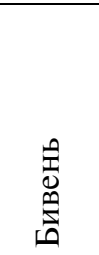 & 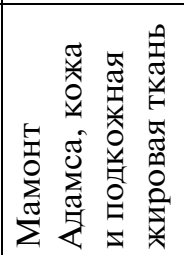 & 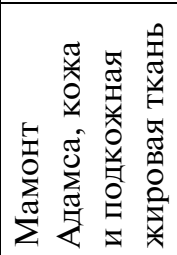 & $\stackrel{\widetilde{\pi}}{\leftarrow}$ & 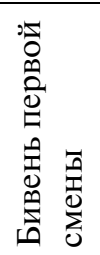 & 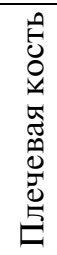 \\
\hline
\end{tabular}

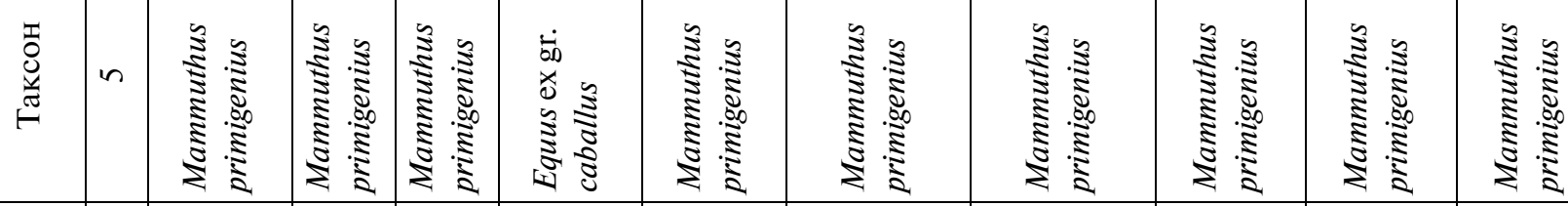

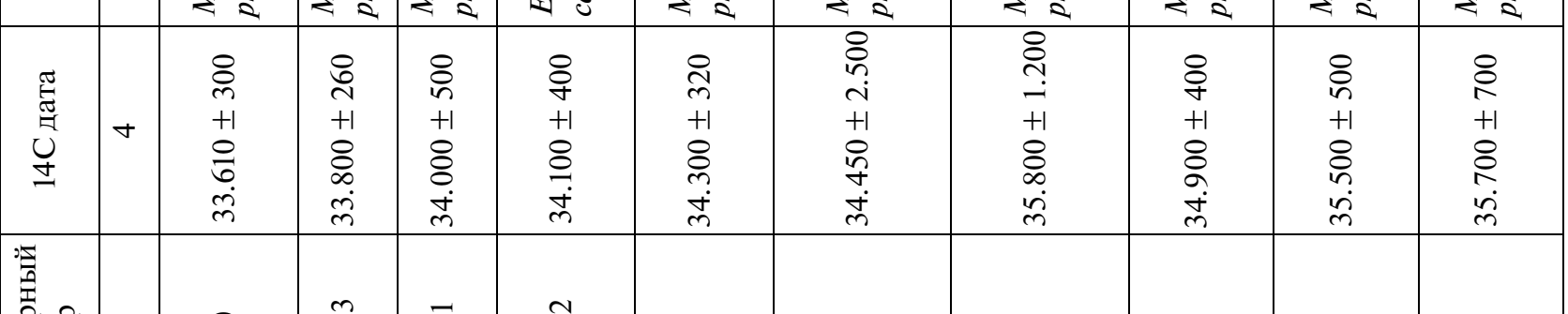

\begin{tabular}{|c|c|c|c|c|c|c|c|c|c|c|c|}
\hline 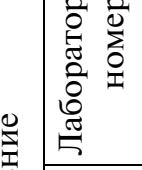 & $m$ & $\begin{array}{l}8 \\
\infty \\
a \\
i \\
z\end{array}$ & 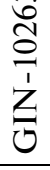 & 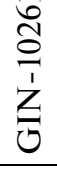 & $\begin{array}{l}\text { ָิ } \\
\frac{1}{1} \\
\text { ż } \\
0\end{array}$ & $\begin{array}{l}n \\
2 \\
a \\
i \\
z \\
0\end{array}$ & 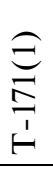 & 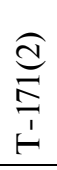 & $\begin{array}{l}\hat{a} \\
\dot{\alpha} \\
\hat{i} \\
0\end{array}$ & $\begin{array}{l}\infty \\
\infty \\
a \\
i \\
\vdots \\
0\end{array}$ & 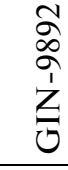 \\
\hline 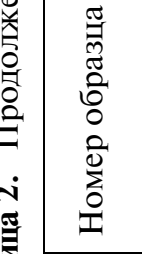 & $\sim$ & $\begin{array}{l}0 \\
0 \\
0 \\
0 \\
1 \\
\dot{v} \\
\Sigma\end{array}$ & 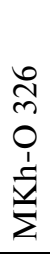 & $\begin{array}{l}m \\
\hat{n} \\
0 \\
1 \\
\vdots \\
\Sigma \\
\Sigma\end{array}$ & 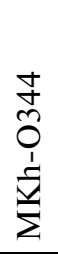 & $\begin{array}{l}n \\
\tilde{n} \\
0_{1} \\
\vdots \\
\Sigma \\
\Sigma\end{array}$ & & & 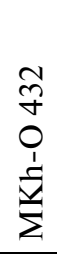 & $\begin{array}{l}0 \\
0 \\
0 \\
0 \\
1 \\
1 \\
\vdots \\
\Sigma\end{array}$ & 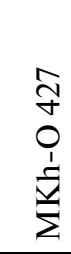 \\
\hline z & - & ñ & $m$ & $\stackrel{+}{m}$ & $\tilde{m}$ & lల & $\bar{n}$ & $\stackrel{\infty}{m}$ & ले & P & $F$ \\
\hline
\end{tabular}




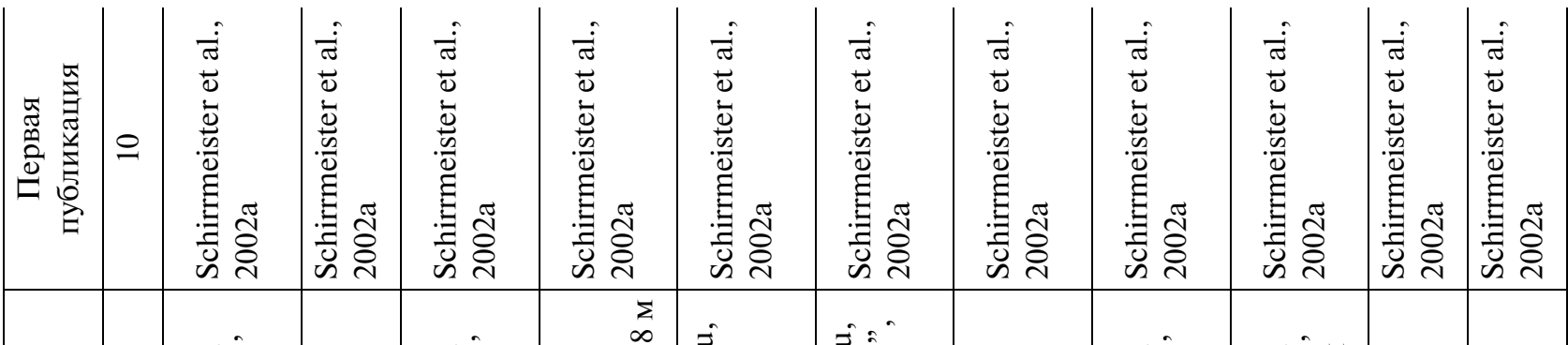

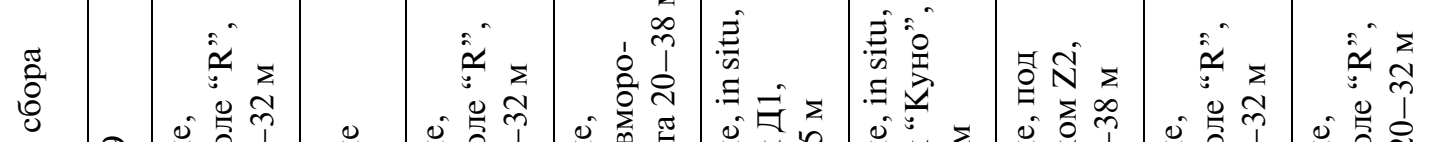

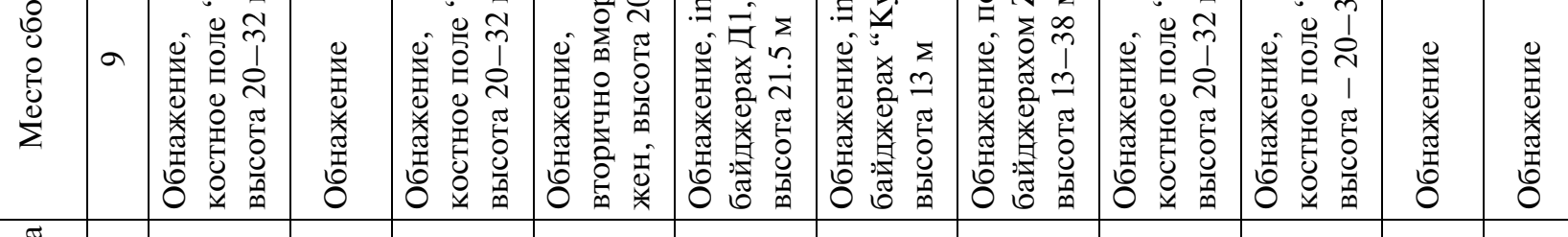

\begin{tabular}{|c|c|c|c|c|c|c|c|c|c|c|c|c|}
\hline 舀 & $\infty$ & م & 0 & م & م & $\pi$ & $\sigma$ & 0 & 0 & 0 & 0 & 0 \\
\hline
\end{tabular}

\begin{tabular}{|c|c|c|c|c|c|c|c|c|c|c|c|c|}
\hline 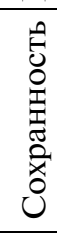 & $r$ & & & 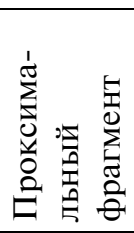 & 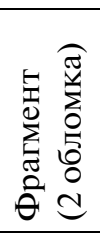 & 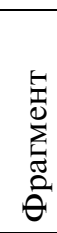 & 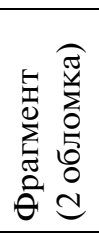 & 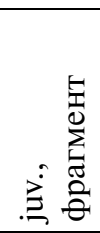 & & 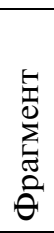 & 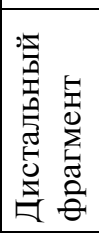 & \\
\hline 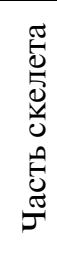 & 6 & 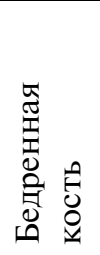 & 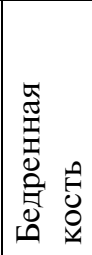 & 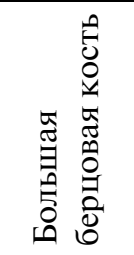 & 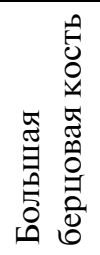 & 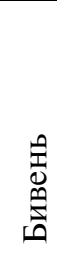 & م. & 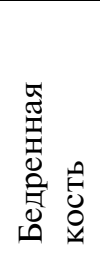 & 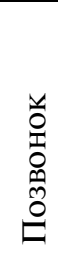 & $\stackrel{\mathscr{\pi}}{\sim}$ & 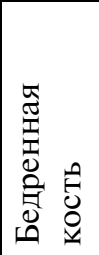 & 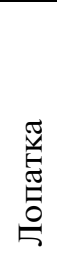 \\
\hline
\end{tabular}

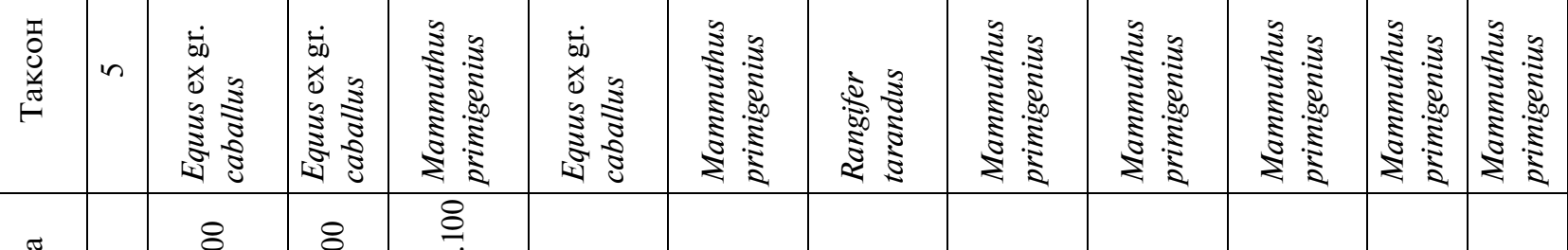

\begin{tabular}{|c|c|c|c|c|c|c|c|c|c|c|c|c|}
\hline 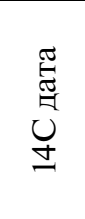 & | & $\begin{array}{l}8 \\
8 \\
+1 \\
8 \\
8 \\
\infty \\
\dot{m}\end{array}$ & $\begin{array}{l}8 \\
8 \\
+1 \\
8 \\
8 \\
\text { ஜे }\end{array}$ & $\begin{array}{l}8 \\
\varrho \\
+1 \\
+1 \\
8 \\
\stackrel{n}{+} \\
\dot{f}\end{array}$ & 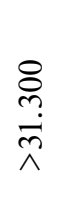 & $\begin{array}{l}\stackrel{8}{0} \\
\stackrel{\sim}{\wedge} \\
\end{array}$ & 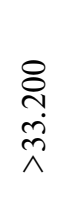 & 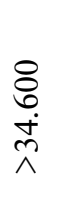 & $\begin{array}{l}8 \\
\stackrel{8}{n} \\
i n \\
\end{array}$ & $\begin{array}{l}\stackrel{8}{R} \\
\dot{n} \\
\stackrel{\lambda}{n}\end{array}$ & 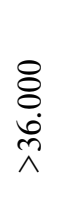 & $\begin{array}{l}\stackrel{8}{8} \\
\dot{+} \\
\wedge \\
\wedge\end{array}$ \\
\hline
\end{tabular}

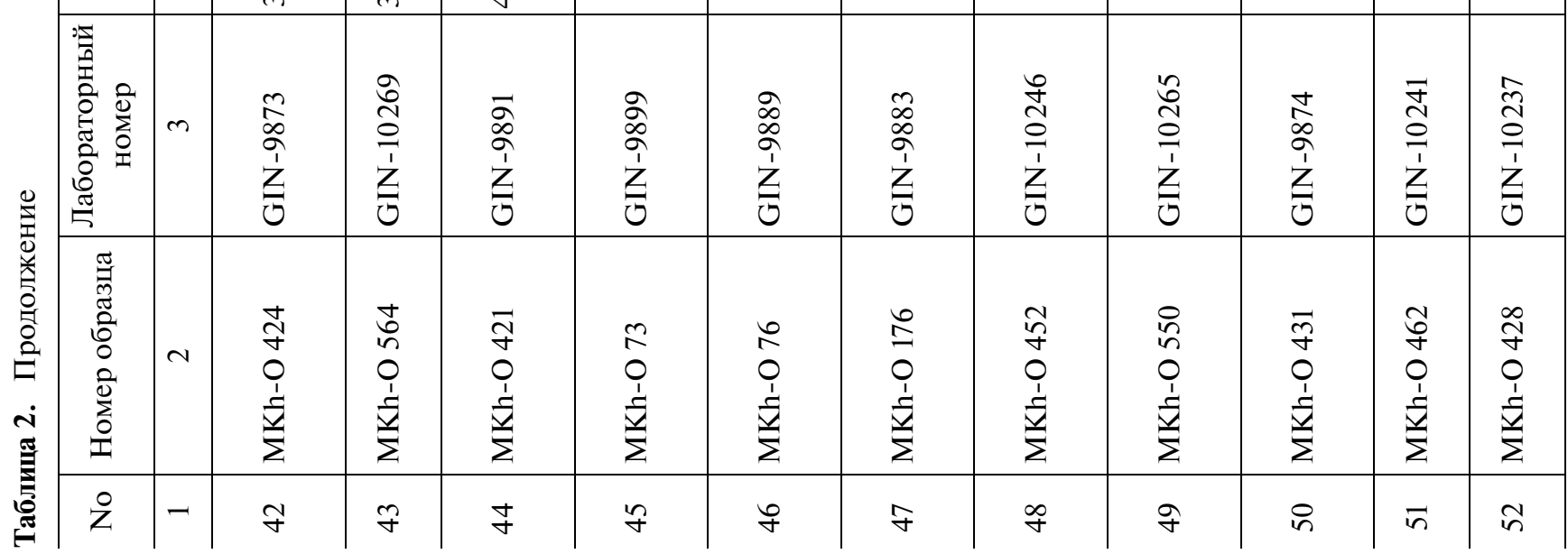




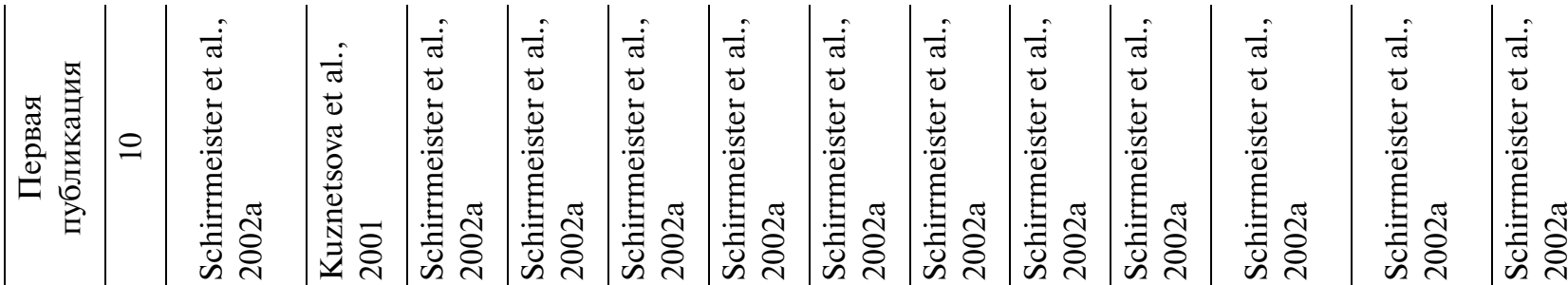

\begin{tabular}{|c|c|c|c|c|c|c|c|c|c|c|c|c|c|}
\hline 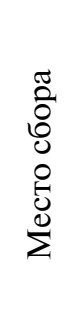 & $a$ & 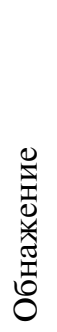 & 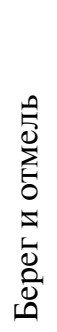 & 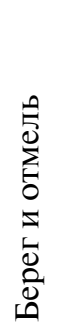 & 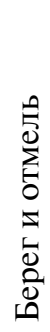 & $\begin{array}{l}\text { D. } \\
0 \\
\sum_{i}^{0} \\
0 \\
\vdots \\
\overrightarrow{0} \\
0 \\
0 \\
0\end{array}$ & 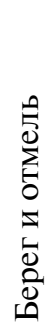 & $\begin{array}{l}\text { D } \\
\sum_{i}^{0} \\
0 \\
\Xi \\
\overrightarrow{0} \\
0 \\
0 \\
0\end{array}$ & 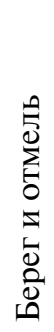 & 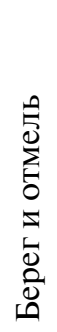 & 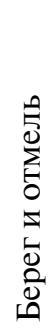 & 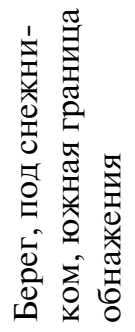 & 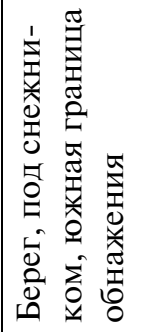 \\
\hline 䚄 & $\infty$ & 0 & $\nabla$ & $\nabla$ & $\sigma$ & $\nabla$ & $\sigma$ & $\nabla$ & $\sigma$ & $\nabla$ & $\tau$ & $\nabla$ & $\sigma$ \\
\hline
\end{tabular}

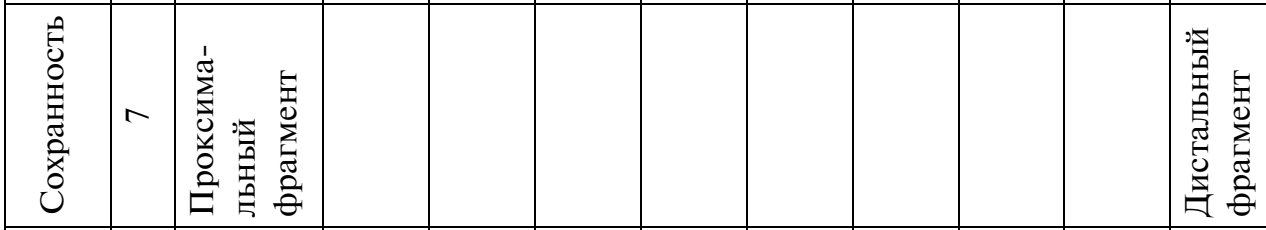

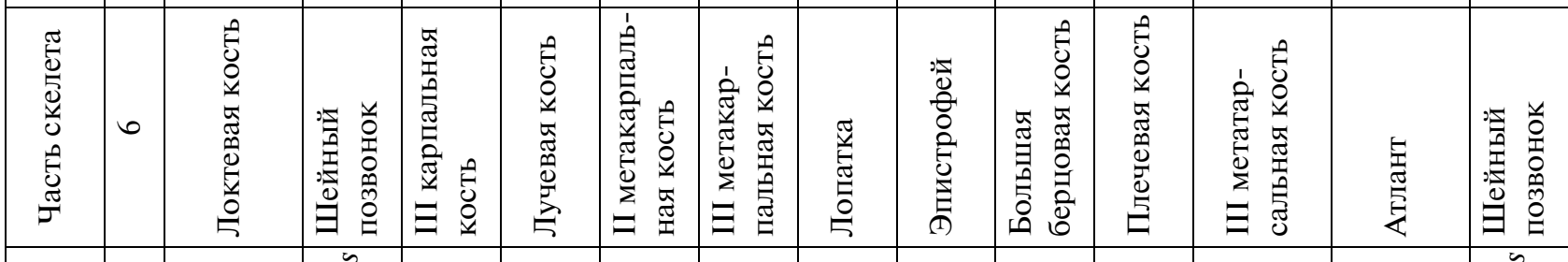

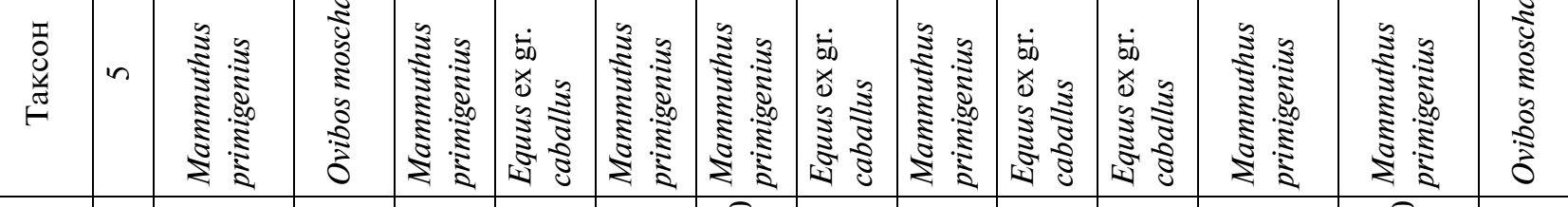

\begin{tabular}{|c|c|c|c|c|c|c|c|c|c|c|c|c|c|c|}
\hline 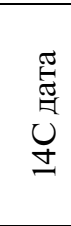 & $\nabla$ & $\begin{array}{l}8 \\
\stackrel{8}{7} \\
\stackrel{+}{*}\end{array}$ & 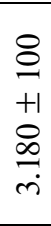 & 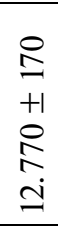 & 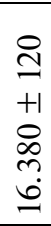 & $\begin{array}{l}8 \\
8 \\
+1 \\
8 \\
8 \\
0 \\
0\end{array}$ & 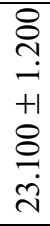 & 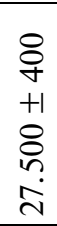 & 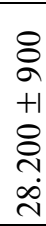 & $\begin{array}{l}\text { in } \\
+ \\
+1 \\
8 \\
8 \\
\stackrel{2}{2}\end{array}$ & $\begin{array}{l}\text { \& } \\
+1 \\
+1 \\
8 \\
8 \\
\text { ते }\end{array}$ & $\begin{array}{l}8 \\
6 \\
+1 \\
8 \\
n \\
\text { m. }\end{array}$ & $\begin{array}{l}8 \\
8 \\
8 \\
\dot{8} \\
+1 \\
8 \\
8 \\
\dot{+}\end{array}$ & 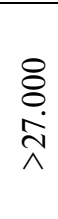 \\
\hline
\end{tabular}

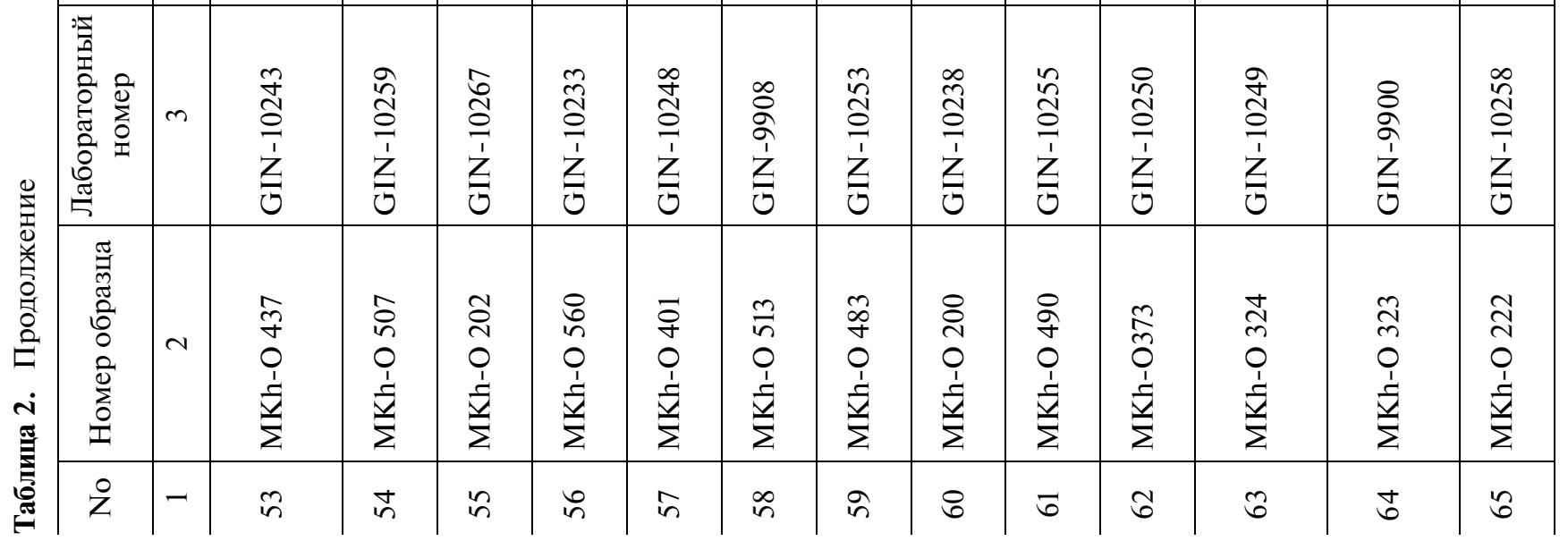


КУЗНЕЦОВА и др.

\begin{tabular}{|c|c|c|c|c|c|c|c|c|c|c|c|c|c|c|c|}
\hline 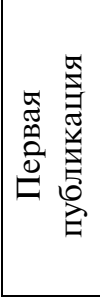 & $\varrho$ & 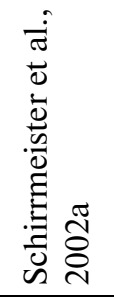 & 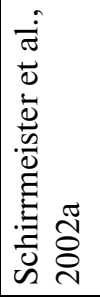 & 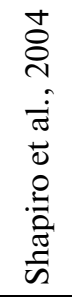 & 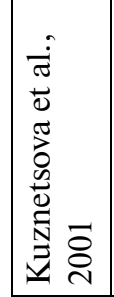 & 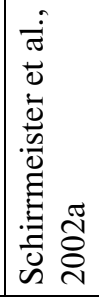 & 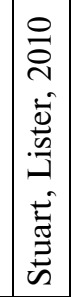 & 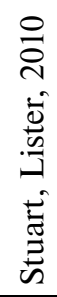 & 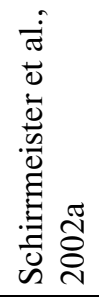 & 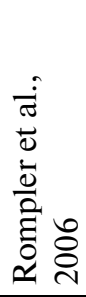 & & & 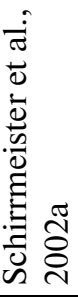 & 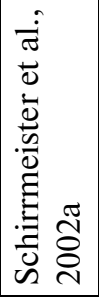 & 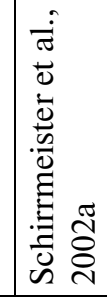 \\
\hline
\end{tabular}

\begin{tabular}{|c|c|c|c|}
\hline 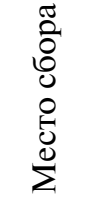 & $a$ & 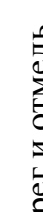 & \\
\hline
\end{tabular}

\begin{tabular}{|c|c|c|c|c|c|c|c|c|}
\hline 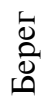 & 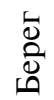 & $\begin{array}{l}\overrightarrow{0} \\
\frac{0}{0} \\
0\end{array}$ & $\begin{array}{l}\tilde{v} \\
\stackrel{\partial}{u} \\
\emptyset\end{array}$ & 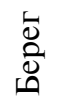 & $\begin{array}{l}\vec{v} \\
\stackrel{0}{u} \\
\emptyset\end{array}$ & $\begin{array}{l}\vec{v} \\
\stackrel{\nu}{u} \\
\emptyset\end{array}$ & $\begin{array}{l}\overrightarrow{\tilde{D}} \\
\stackrel{0}{0} \\
\underline{b}\end{array}$ & 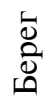 \\
\hline 0 & 0 & 0 & 0 & 0 & 0 & 0 & 0 & 0 \\
\hline
\end{tabular}

\begin{tabular}{|l|l|l|l|l|}
\hline 茎 & $\infty$ & 0 & 0 & 0 \\
\hline \multirow{2}{*}{} & & & & \\
\hline
\end{tabular}

\begin{tabular}{|c|c|c|c|}
\hline 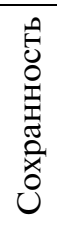 & $r$ & 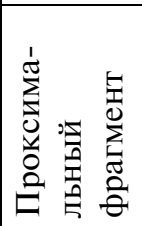 & 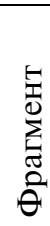 \\
\hline
\end{tabular}

\begin{tabular}{|c|c|c|c|c|}
\hline 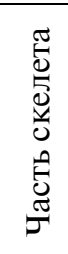 & 6 & 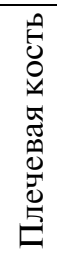 & 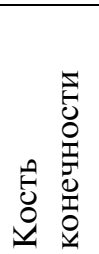 & 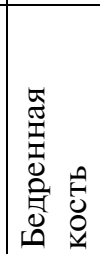 \\
\hline & & & & \\
\hline
\end{tabular}

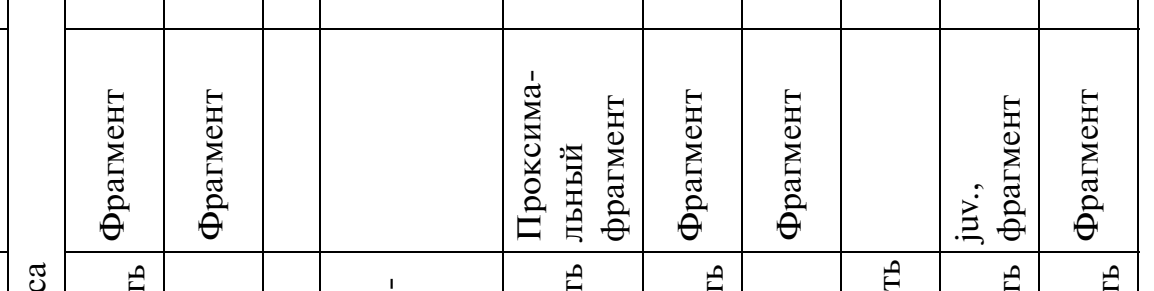

\begin{tabular}{|c|c|c|c|c|}
\hline 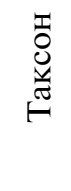 & in & 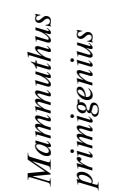 & 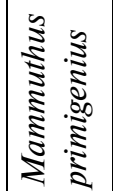 & $\begin{array}{l}0 \\
0 \\
0 \\
0 \\
0 \\
0 \\
0 \\
0 \\
0 \\
0\end{array}$ \\
\hline
\end{tabular}

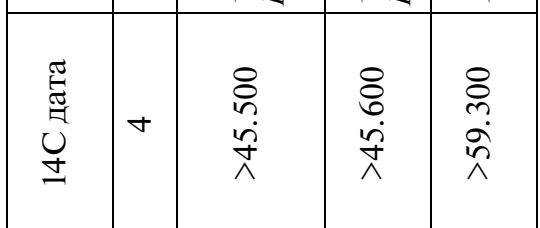

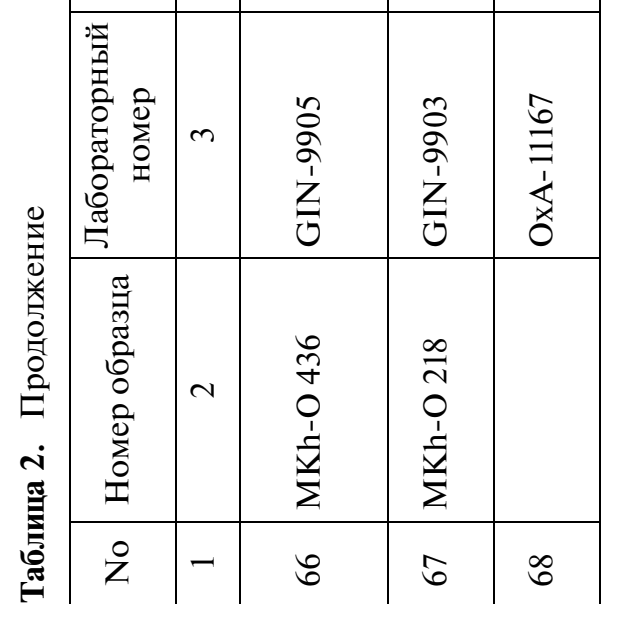

\begin{tabular}{|c|c|c|c|c|c|c|c|c|c|}
\hline 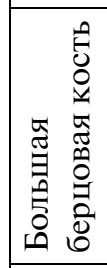 & $\stackrel{\infty}{\Theta}$ & 兰 & 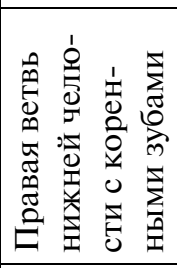 & 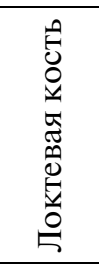 & 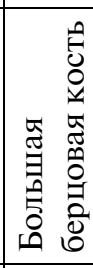 & 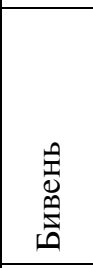 & 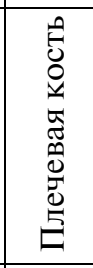 & 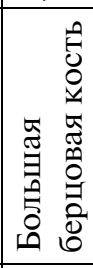 & 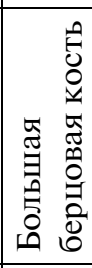 \\
\hline 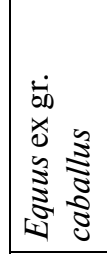 & 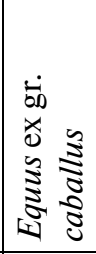 & 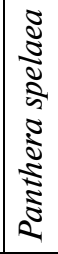 & 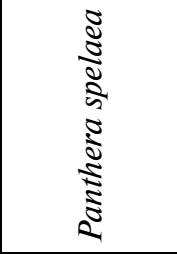 & 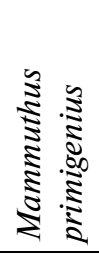 & 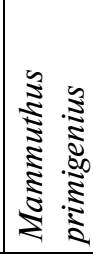 & 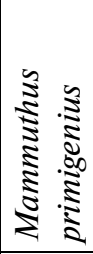 & 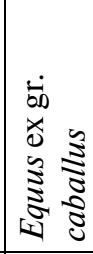 & 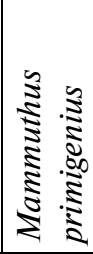 & 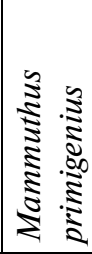 \\
\hline $\begin{array}{l}\stackrel{+}{+} \\
+1 \\
0 \\
\frac{0}{\sigma} \\
\dot{+}\end{array}$ & $\begin{array}{l}8 \\
8 \\
\text { + } \\
+1 \\
8 \\
+ \\
+ \\
\text { i } \\
\end{array}$ & 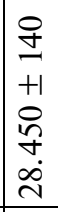 & $\begin{array}{l}o \\
+ \\
+1 \\
o \\
n \\
n \\
\infty \\
i \\
\end{array}$ & 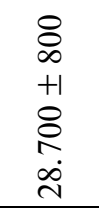 & 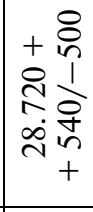 & $\begin{array}{l}\infty \\
\infty \\
+1 \\
8 \\
\infty \\
\infty \\
\infty \\
\end{array}$ & 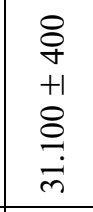 & $\begin{array}{l}8 \\
8 \\
+1 \\
+1 \\
8 \\
n \\
i \\
n \\
\end{array}$ & $\begin{array}{l}\stackrel{0}{7} \\
+1 \\
+1 \\
8 \\
8 \\
\dot{0} \\
\dot{m}\end{array}$ \\
\hline 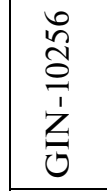 & $\frac{\hat{n}}{\hat{\sigma}}$ & 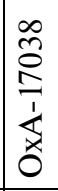 & 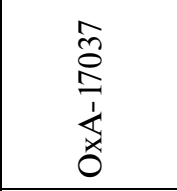 & $\begin{array}{l}0 \\
\stackrel{2}{\circ} \\
\text { ì } \\
\text { ż }\end{array}$ & 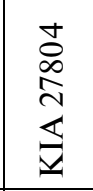 & $\begin{array}{l}\text { ¿ } \\
\text { à } \\
\text { ż } \\
0\end{array}$ & $\begin{array}{l}\overline{1} \\
\infty \\
\hat{i} \\
z \\
0\end{array}$ & $\begin{array}{l}\bar{\sigma} \\
\text { à } \\
\text { ż } \\
0\end{array}$ & \begin{tabular}{l}
+ \\
$\infty$ \\
$\infty$ \\
\multirow{1}{1}{} \\
$Z$ \\
0
\end{tabular} \\
\hline $\begin{array}{l}\tilde{2} \\
\tilde{n} \\
0 \\
\frac{1}{2} \\
\frac{1}{2} \\
\Sigma\end{array}$ & $\begin{array}{l}\hat{8} \\
0 \\
0 \\
1 \\
\vdots \\
\vdots \\
\Sigma\end{array}$ & $\begin{array}{l}\tilde{N} \\
\tilde{N} \\
0 \\
\frac{1}{\tilde{a}} \\
\underline{\Sigma}\end{array}$ & $\begin{array}{l}\tilde{N} \\
0 \\
0 \\
\frac{1}{\tilde{a}} \\
\Sigma\end{array}$ & $\begin{array}{l}n \\
b \\
+ \\
0 \\
\frac{1}{2} \\
\frac{1}{2}\end{array}$ & $\begin{array}{l}\infty \\
0 \\
0 \\
0 \\
1 \\
\dot{1} \\
\Sigma \\
\Sigma\end{array}$ & $\begin{array}{l}\hat{b} \\
+ \\
0 \\
\frac{1}{d} \\
\frac{1}{2}\end{array}$ & $\begin{array}{l}n \\
\hat{n} \\
0 \\
\frac{1}{2} \\
\frac{1}{2}\end{array}$ & $\begin{array}{l}\stackrel{P}{f} \\
0 \\
\frac{1}{1} \\
\frac{1}{2} \\
\Sigma\end{array}$ & $\begin{array}{l}\hat{b} \\
\dot{b} \\
0 \\
\frac{1}{j} \\
\frac{1}{2}\end{array}$ \\
\hline gे & $\stackrel{R}{R}$ & $\nabla$ & $\mathbb{N}$ & $\cong$ & $\stackrel{+}{*}$ & $\stackrel{n}{n}$ & $\stackrel{2}{2}$ & $\hat{\imath}$ & $\pi$ \\
\hline
\end{tabular}




\begin{tabular}{|c|c|c|c|c|c|c|c|c|c|c|c|}
\hline 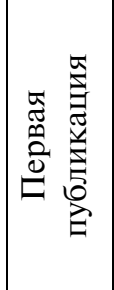 & 의 & 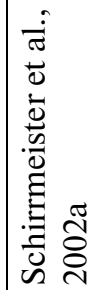 & 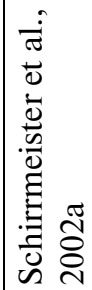 & 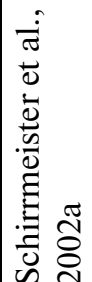 & 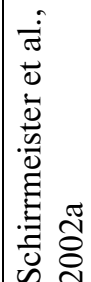 & 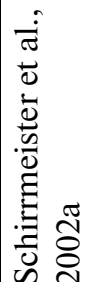 & 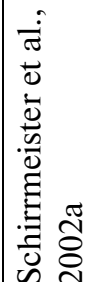 & 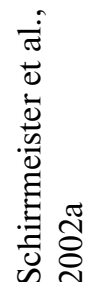 & 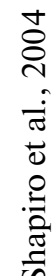 & 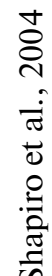 & 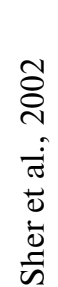 \\
\hline
\end{tabular}

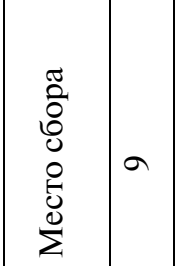

\begin{tabular}{|c|c|c|c|c|c|c|c|c|c|c|c|}
\hline$\Sigma$ & & ڤั) & ڤે & ڤે & 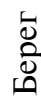 & 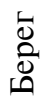 & ڤે & 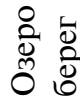 & 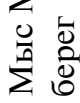 & 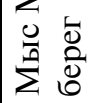 & 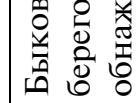 \\
\hline 皛 & $\infty$ & 0 & 0 & 0 & 0 & 0 & 0 & 4 & 4 & 4 & \\
\hline
\end{tabular}

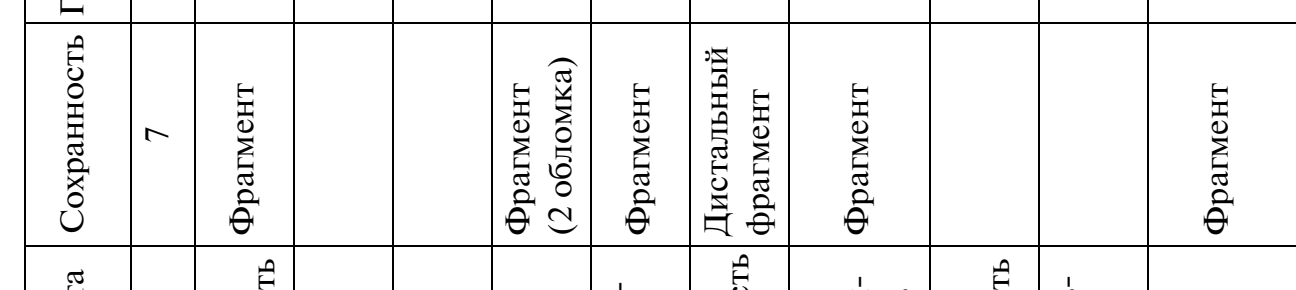

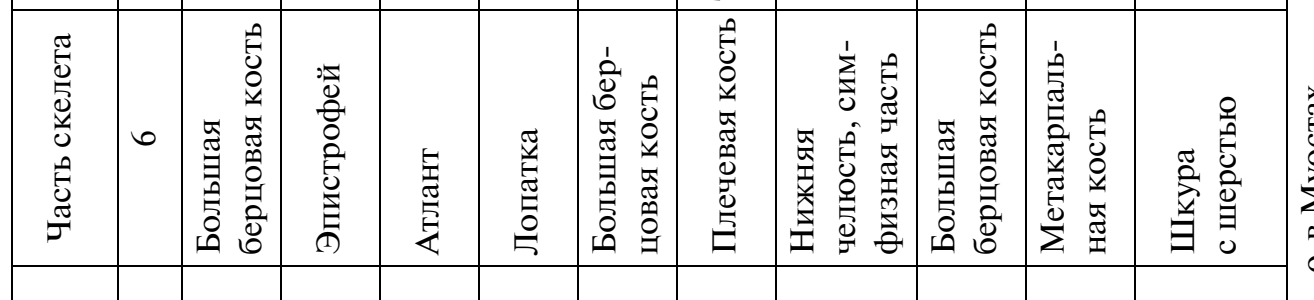

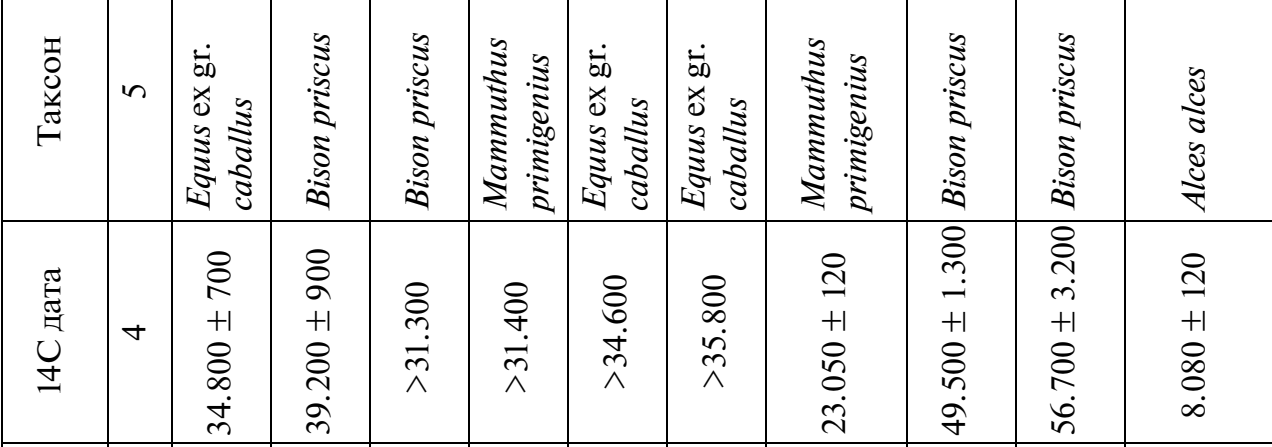

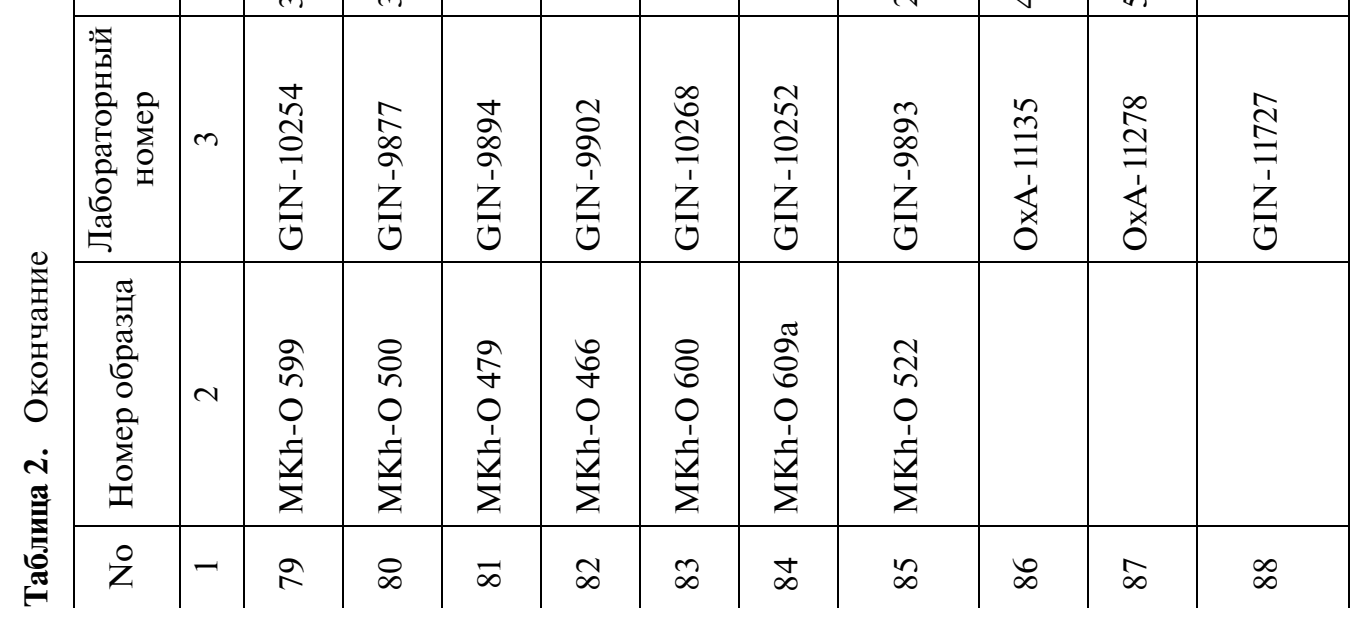

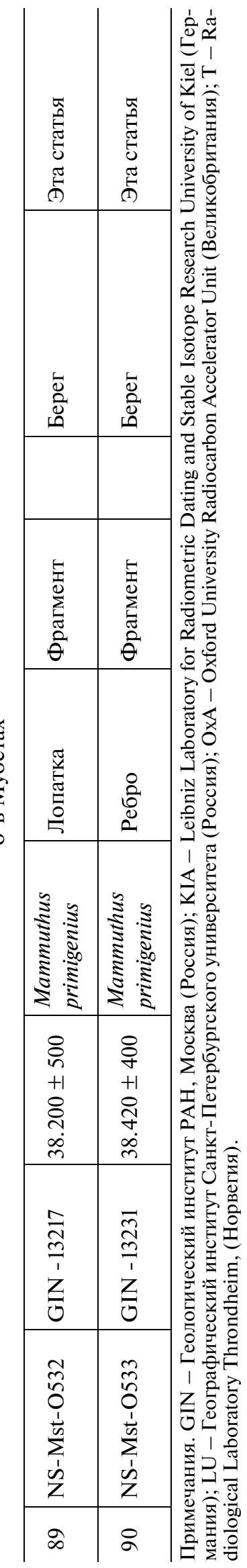


одну кость скелета, чтобы на $100 \%$ исключить смешение дат.

Радиоуглеродный возраст нескольких мелких фрагментов костей, мелкие кости, найденные in situ (группа "а"), а также интересных образцов, найденных в осыпи и на берегу, определяли AMS методом. Очень хорошая сохранность коллагена в образцах подтверждается исследователями и в лабораториях, где было проведено AMS датирование: Leibniz Laboratory for Radiometric Dating and Stable Isotope Research University of Kiel (Германия) и Oxford University Radiocarbon Accelerator Unit (Великобритания).

В работе приводятся радиоуглеродные, не калиброванные даты.

\section{Краткая геолого-геоморфологическая характеристика района исследований}

Восточное побережье Быковского п-ова представляет собой аккумулятивно-абразионный берег, протягивающийся почти на 40 км с юго-востока на северо-запад (рис. 1). Береговой обрыв подрезает две основные формы рельефа полуострова - едомные возвышенности и аласные котловины. Едомы высотой до 41 м сложены поздненеоплейстоценовыми и раннеголоценовыми аллювиальными и пролювиально-делювиальными пылеватыми суглинками и супесями с горизонтами полигональных торфяников. Они содержат мощные сингенетические повторно-жильные льды, имеют высокую суммарную льдистость и по криолитологическим характеристикам являются ледовым комплексом.

Крупная едомная возвышенность с высотами до 40-41 м над ур. м. расположена в юго-восточной части Быковского п-ова. Её восточная часть разрушается морем и формирует берег, северный участок которого, протяжённостью примерно 3.5 км, носит название урочище Мамонтовый Хайата. В направлении на север едомная возвышенность сменяется аласной котловиной, побережье которой называется урочище Мамонтовый Бысагаса. Отметки высот ее поверхности не превышают 4-5 м и понижаются до 1-2 м вблизи северного края котловины. В 2 км севернее урочища Мамонтовый Хайата она ограничена следующей едомной возвышенностью. Последняя протягивается на север вдоль берега и через 5 км образует выступ в береговой линии, известный как мыс Мамонта. Вдоль всего побережья этой безымянной едомы почти до мыса Мамонт протягивается краевая часть аласной котловины, практически полностью размытой морем. Ее аласные террасы шириной от 100 до 300 м особенно хорошо выражены в северной части. Участок побережья, в пределах которого развиты эти аласные террасы, в статье будет называться Мамонтовой террасой.
Образование этих, как и многих других аласных котловин, связано с протаиванием отложений ледового комплекса под термокарстовыми озерами в начале голоценового потепления. После дренирования термокарстовых озер, которое может происходить в несколько этапов, образуются обширные округлые аласные котловины, часто террасированные. В геологическом отношении разрез аласной котловины представлен с поверхности отложениями собственно-аласной (болотной) фации - полигональными торфяниками с подстилающими их оторфованными пылеватыми суглинками, включающими ледяные жилы шириной до 2.5-3 м. Ниже залегают озерные отложения, а под ними - таберальные образования ледового комплекса.

В пределах южной части Мамонтовый Бысагаса в береговом уступе вскрываются только собственно-аласные отложения, а в пределах ее северной части даже они почти уходят под уровень моря. В пределах второй аласной котловины, к которой относится Мамонтовая терраса, береговые обнажения часто закрыты осыпями, однако местами в пределах Мамонтовой террасы в основании видимой части разреза вскрываются озерные отложения и даже верхи таберальных образований. В верхней части обрыва местами вскрываются полигональные торфяники, под которыми расположены вторично-промерзшие осыпи.

Мамонтовый Хайата. Наиболее изученным является обнажение Мамонтовый Хайата (рис. 1), высота бровки которого достигает 38 м над ур. м. Благодаря совместному развитию морской термоабразии, термоденудации и термоэрозии, поверхность обнажения представляет собой серию из нескольких термотеррас, высота которых меняется вдоль обнажения. Между собой термотеррасы местами разделены активно растущими термоэрозионными оврагами, на их поверхности обычно присутствуют байджерахи разной степени сохранности - столбообразные или конические бугры поперечником порядка 10 м, образующиеся в результате вытаивания окружающих их ледяных жил. Поверхность обнажения очень динамична и может полностью измениться всего за несколько лет. Поэтому кости, которые найдены на поверхности обнажения, обычно имеют довольно хорошую сохранность, т.к. не могут находиться на его поверхности дольше 2-3 лет. В собранной коллекции они обычно входят в 13 группы сохранности.

Подошва отложений ледового комплекса расположена на Мамонтовый Хайате ниже уровня моря примерно на 10-15 м (Слагода, 2004). Нижние 20-25 м отложений представлены пылеватыми супесями аллювиального происхождения. На высоте 10-15 м над ур. м. они перекрываются горизонтом полигональных автохтонных торфяни- 
ков молотковского возраста (Shirrmeister et al., 2002, 2002a), еще выше залегают молотковскосартанские пылеватые суглинки. По особенностям микростроения и условиям залегания они рассматриваются как делювиально-пролювиальные отложения (Слагода, 2004). В верхней части разреза льдистые отложения ледового комплекса перекрываются покровным горизонтом мощностью до 2 м, происхождение которого связывается с площадной термопланацией высокольдистых едомных отложений в первой половине голоцена. Он практически не содержит ледяных жил, но имеет все равно достаточно высокую льдистость. Термотеррасы обычно формируются на уровне горизонта торфяников, часто образуются в нижней части обнажения. Скорость отступания берега по бровке составляет в среднем 46 м/год (Григорьев, 1993).

Мамонтовая терраса. Береговой обрыв террасы (рис. 1) достигает высоты 7-10 м над ур. м., в связи с чем, как упоминалось выше, здесь вскрывается не только верхний горизонт аласных отложений (Kuznetsova et al., 1999). Нижняя часть разреза, видимой мощностью 5 м, сложена суглинками с линзами мелкозернистого песка и растительного детрита. По криогенному строению ее можно рассматривать как таберальные образования ледового комплекса. Верхняя часть разреза, мощностью до 3.5 м, сложена суглинками и мелкозернистым песком с большим количеством различных растительных остатков (прибрежно-озерная фация), а венчается линзами автохтонных полигональных торфов (собственно-аласные отложения). Эта часть разреза содержит сингенетические ледяные жилы шириной до 2 м. Отложения мелкозернистого песка включают большое количество разнообразных фрагментов крупных кустарников. Отдельные ветки кустарников, покрытые корой можно отнести к ольхе или березе. Кроме кустарников есть части стволов деревьев и пни, захороненные, иногда, в прижизненном положении, возможно, это остатки лиственниц. В этих же песках найдены раковины пресноводных двустворчатых моллюсков и гастропод. Возраст озерных отложений определен по растительным остаткам, около 9.5-9 тыс. л. н. (9067 \pm 230 л. н. (PI-1181), $9443 \pm 242$ л. н. (PI-2000) и $9475 \pm 40$ л. н. (KIA 6739)) (Kuznetsova et al., 1999).

Верхние суглинки - отложения собственно аласной фации, включают большое количество линз автохтонного торфа. Радиоуглеродный возраст одной из них был определен как $5316 \pm 193$ л. н. (PI-1999) (Kuznetsova et al., 1999).

\section{РЕЗУЛЬТАТЫ}

\section{Палеозоологические исследования}

Основной палеонтологический материал с Быковского п-ова был собран нами на обнажениях Мамонтовый Хайата и Мамонтовая терраса в 1998 г. (Siegert et al., 1999), уточняющее изучение обнажений и сбор палеонтологического материала проводился также в 1999, 2000 и 2001 годах (Sher et al., 2000, 2002; Schirrmeister et al., 2001). Единичные образцы с обнажения Мамонтовый Хайата поступали и в последующие годы.

Коллекция млекопитающих мамонтового комплекса, собранная на обнажениях Быковского п-ова насчитывает 1191 образец, из них 1136 образцов (95.4\%) определено (табл. 1). В процентном отношении (от определенных образцов) преобладают остатки Mammuthus primigenius (Blumenbach 1799) - 36.9\%, Equus ex gr. caballus L. $1758-23.7 \%$, Rangifer tarandus L. $1758-14.4 \%$ и Bison priscus (Bojanus 1827) - 13.0\% (рис. $2 a$ ). Из всех видов, входивших в мамонтовый комплекс, в настоящее время на рассматриваемой территории обитает лишь северный олень. По-видимому, остатки северных оленей в коллекции представлены не только ископаемыми, но и современными образцами. Разделить остатки ископаемых и современных северных оленей по сохранности невозможно, т.к. из-за действия морозного выветривания и воды (соленой или пресной) по внешнему виду нельзя отличить ископаемые и современные кости. Остатки северных оленей, найденные на поверхности тундры, авторы не собирали, т.к. считали их современными. Однако то, что среди находок велика доля остатков северного оленя, все же определяется попадание в коллекцию современного материала. Только кости представителей этого вида, найденные в отложениях in situ, можно четко относить к ископаемым.

Мамонтовый Хайата. Непосредственно на разрезе Мамонтовый Хайата собрано всего 209 образцов (17.5\% от всей коллекции, группы “a”, “b”, “c”), из них 191 образец (91.4\%) определен до вида. Для области развития ледового комплекса на разрезе собрано большое количество образцов $17.5 \%$ от общего числа коллекции. Например, на обнажении Ойогосский яр образцов с разреза всего 134 из 1607, что составляет лишь 8.3\% от всей коллекции (по данным авторов). С разреза Мамонтовый Хайата преобладают костные остатки мамонтов - 39.3\%, северных оленей $-18.8 \%$, плейстоценовых зайцев $-17.8 \%$, лошадей $-15.2 \%$ и бизонов $-5.2 \%$ (рис. $2 b$ ). Из 30 костных остатков, найденных in situ (группа “а”), 11 - зайцы, 6 - северные олени, 5 - мамонты, 2 - лошади, остальные фрагменты костей не определены. Значительное количество находок зайцев объясняется тем, что у авторов была возможность длительное время и очень подробно изучать обнаже- 
$a$

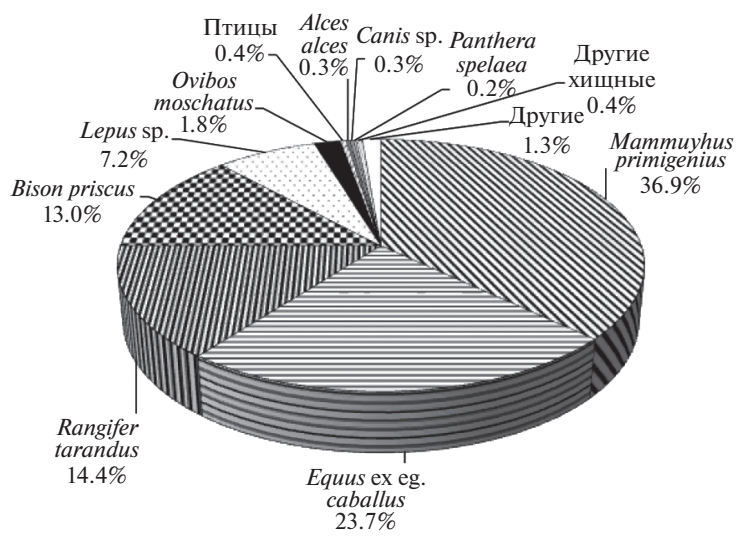

c

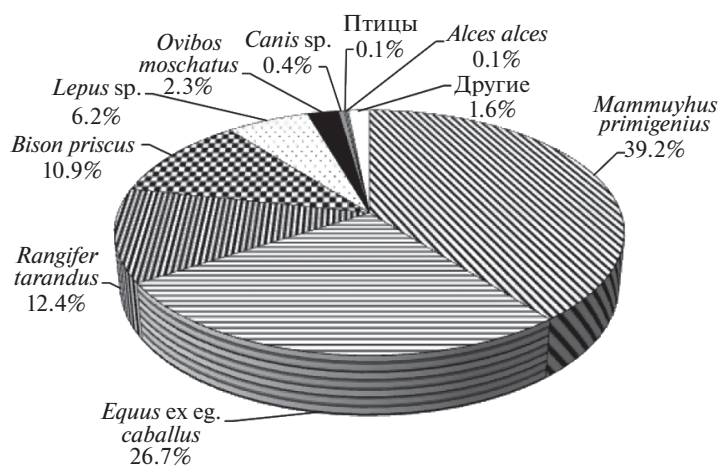

$e$

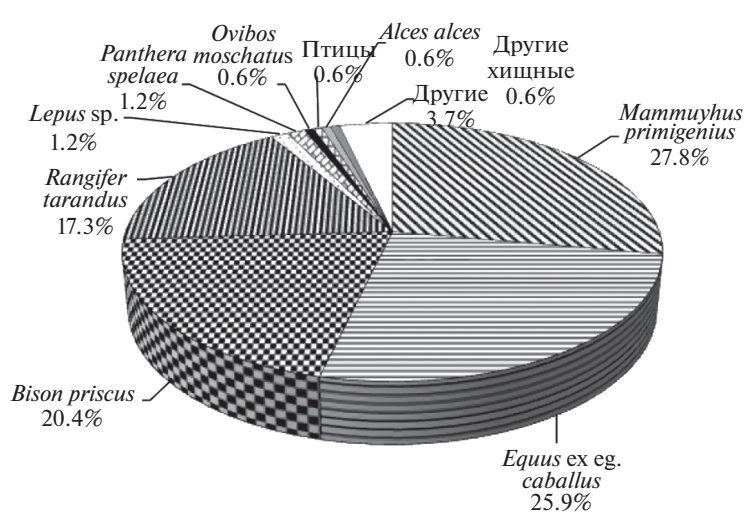

$b$

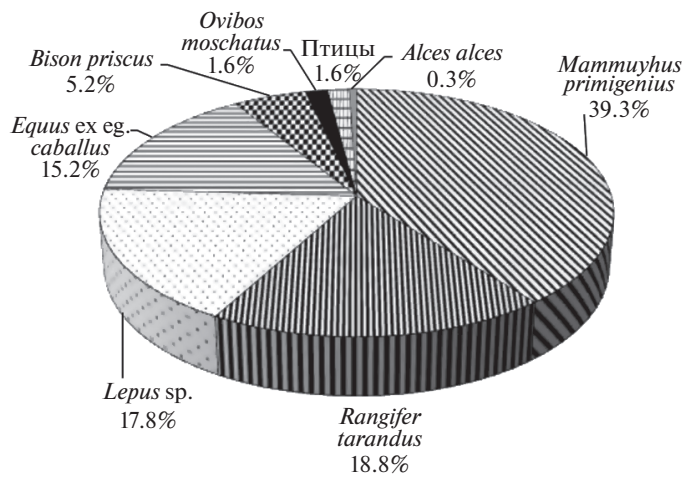

$d$

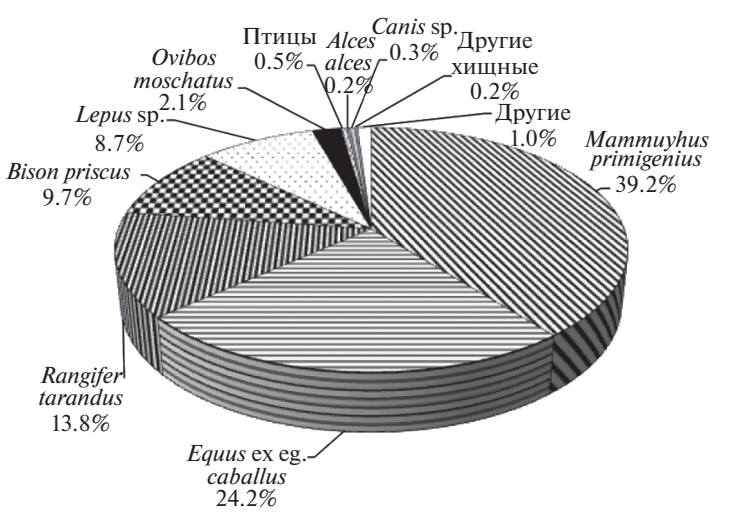

Рис. 2. Процентное соотношение находок представителей мамонтовой фауны. Для построения графиков учитывались только таксономически атрибутированные образцы. $a-$ на Быковском п-ове (всего 1136 образцов); $b-$ на обнажении Мамонтовый Хайата, группы “a”, “b”, “c” (всего 191 образец); $c$ - на берегу и отмели под обнажением Мамонтовый Хайата, группа “d” (всего 696 образцов); $d$ - на обнажении Мамонтовый Хайата и под ним, группы “а”, “b”, “с”, “d”, (всего 887 образцов); $e$ - на обнажении Мамонтовая терраса, группы “е” (всего 162 образца).

ние. Особенности разрушения и оттаивания пород ледового комплекса позволяют находить в слое значительно больше мелких костей и фрагментов костей по сравнению с крупными костями. Возможно поэтому доля находок зайцев с разреза (17.8\%) значительно больше, чем в целом в коллекции (8.7\%). Зайцы-беляки (Lepus timidus L. 1758) в настоящее время обитают в дельте р. Лена, однако плейстоценовые зайцы относятся к другому виду - L. tanaiticus Gureev 1964, подвид L. tanaiticus vereschagini Averianov 1995 (Averianov et al., 2003). 
Если рассматривать процентное соотношение остатков млекопитающих, собранных на берегу и отмели (группа “d”), то также преобладают 5 перечисленных выше видов, но в другом порядке. Среди костей, собранных на берегу и береговой отмели (всего 721 образец, из них 25 неопределимых фрагментов костей), преобладают мамонты (39.2\%), лошади (26.7\%), северные олени (12.4\%), бизоны (10,9\%) и зайцы (6.2\%) (рис. $2 c)$. Как было отмечено выше, количество остатков зайцев, найденных не на обнажении, значительно меньше из-за размера животного и хрупкости его костей.

Таким образом, объединив все находки, собранные на Мамонтовый Хайате, можно сделать вывод, что в позднем неоплейстоцене на данной территории из крупных млекопитающих в значительном количестве обитали мамонты, лошади, северные олени и бизоны (рис. $2 d$ ). Овцебыки были представлены в значительно меньшем количестве, всего $2.1 \%$ от общего числа находок, единичны находки остатков лося. Остатки шерстистого носорога отсутствуют.

Среди мелких млекопитающих, собранных из отложений ледового комплекса, голоценовых пролювиально-делювиальных (“ложковых”) отложений, на берегу и отмели (Siegert et al., 1999), преобладают плейстоценовые зайцы L. tanaiticus verrschagini, составляющие $8.7 \%$ от всей коллекции. Остатки грызунов собраны как с обнажения, так и с берега. В 22 промытых с обнажения пробах in situ было найдено всего 35 фрагментов скелета, относящихся к Lemmus ex gr. sibiricus Kerr 1792, Dicrostonyx ex gr. torquatus Pallas 1799 u Microtus sp. (Кузнецова, Тесаков, 2003). Большое количество, в основном, зубов грызунов (34 экз.) и фрагментов скелета, было собрано на берегу, под ложковыми отложениями на юго-восточной оконечности разреза Мамонтовый Хайата. Вероятно, на этой части берега произошла естественная отмывка мелких костей и зубов грызунов, зубов и фрагментов костей скелета зайцев.

Кроме костей млекопитающих, на обнажении были найдены целые и фрагменты плечевых костей птиц - гуся гуменника (Anser fabalis (Latham 1787)), утки шилохвость (Anas acuta L. 1758) и гаги-гребенушки (Somateria spectabilis L. 1758), а на берегу - плечевая кость малого (тундрового) лебедя (Cygnus bewickii Yarrell 1830) (табл. 1). Все определения проводились старшим научным сотрудником кафедры биогеографии географического факультета МГУ им. М.В. Ломоносова А.Н. Калякиным и заведующим Палеонтологическим музеем, старшим научным сотрудником ПИН РАН А.А. Карху.

Мамонтовая терраса. Коллекция костных остатков млекопитающих, собранных из осыпи и на берегу под обнажением Мамонтовая терраса (группа “е”), насчитывает 172 образца (табл. 1). Большая часть костей имеет специфичную сохранность. Это кости с очень темной, почти черной, поверхностью, покрытые вивианитом. Такая форма сохранности, по-видимому, указывает на происхождение костей из таберальных образований аласного комплекса. Это подтверждается и радиоуглеродными датировками костей. Часть костей с более светлой поверхностью (группы 3 и 4 по сохранности), вероятно, происходит из делювиально-солифлюкционных отложений и поступила в краевую часть аласа со склонов едомы. До вида определено 162 образца. Преобладают остатки M. primigenius - $27.8 \%$, незначительно меньше E. ex gr. caballus $-25.9 \%$, B. priscus $-20.4 \%$ и $R$. tarandus $-17.3 \%$. Единичными костями представлены виды $O$. moschatus -2 кости, L. tanaiticus 2 кости, Panthera spelaea Goldfuss $1810-2$ кости и одна кость Martes sp. (рис. 2e). На берегу под обнажением найдены лопатка и три позвонка, возможно, белухи (Delphinapterus leucas Pallas 1776), по-видимому, современные, и фрагмент плечевой кости чернозобой гагары (Gavia arctica (L. 1758)).

Под этим обнажением на берегу найдены костные остатки хищных млекопитающих. Находки хищных очень редки, и 3 кости (1.7\%) из столь небольшого общего количества костей это необычно. К пещерному льву относится правая ветвь нижней челюсти с коренными зубами и клык, а к кунице - фрагмент нижней челюсти без зубов.

Из разреза аласных отложений на высоте 5 м над ур. м. была сделана промывка на грызунов, в которой были найдены зубы и фрагменты скелета Ls. ex gr. sibiricum (6 эКз.) и D. ex gr. torquatus (3 эКз.).

\section{Радиоуглеродное датирование костей}

С Быковского п-ова с обнажения Мамонтовый Хайата до наших работ по проекту было продатировано только два образца при помощи радиоуглеродного метода $\left(\mathrm{C}^{14}\right)$. Это кожа и жировая ткань, взятые от фрагментарно сохранившихся мягких тканей Мамонта Адамса, возраст которых был определен как $34450 \pm 2500$ л. н. и $35800 \pm$ \pm 1200 л. н. (Гейнц, Гарутт, 1964), а также целая кость запястья мамонта возрастом $21630 \pm 240$ л. н. (Томирдиаро и др., 1984).

За время работ по проекту с Быковского п-ова было продатировано 86 образцов (кости, фрагменты костей и фрагмент шкуры с шерстью) крупных млекопитающих мамонтового фаунистического комплекса: мамонт, лошадь, северный олень, бизон, овцебык, пещерный лев и лось. Датировались кости, найденные in situ (группа “a”), образцы, найденные на обнажении Мамонтовый Хайата (группы “b”, “c”), Мамонтовая терраса 
(группа "e"), наиболее интересные находки с берега и отмели (группа “d”), с мыса Мамонт и с берега озера Мамонт (группа "f”) (Shirrmeister et al., 2002a; Sher et al., 2005). Из 86 радиоуглеродных датировок 17 получились неконечными.

Мамонтовый Хайата. С обнажения нами было сделано 50 определений абсолютного возраста, из них 9 - неконечные, и 15 датировок сделано по костям, собранным на берегу и косе, из них 4 имеют неконечные датировки (рис. 3).

Bce образцы, которые были найдены in situ (группа “а”), и которые имели достаточную массу, были продатированы. Из этих 8 образцов, пять фрагментов костей относятся к мамонту и три фрагмента костей - к северному оленю. Две даты получились неконечными. Наиболее древняя датировка in situ получена по сброшенному рогу северного оленя $-29400 \pm 300$ л. н. (ГИН-9870), а наиболее молодая - $14220 \pm 80$ л. н. (ОхА-10679), по фрагменту черепа мамонтенка. Датировка $35500 \pm 500$ л. н. (ГИН-9898) получена по фрагменту бивня мамонта первой смены, который найден in situ в ложковых отложениях голоценового возраста, что говорит о его переносе и переотложении при образовании этих отложений.

Кроме этого, с обнажения было датировано еще 42 образца, из которых 32 образца относятся к группе "b" и 10 образцов к группе “c” (табл. 2). Из 32 образцов группы "b" 28 образцов имеют конечные даты, а 4 даты - неконечные. К группе "c" относятся 7 конечных датировок и 3 - неконечные. В количественном и процентном отношении преобладают мамонты, по которым сделано 30 датировок, из которых 6 неконечные. Четыре датировки были получены по различным костям посткраниального скелета мамонта (лопатка, фрагмент таза, вторая пястная кость и ребро), найденным на разрезе рядом с байджерахом на высоте 12-14 м над ур. м. Они очень близкие по своим значениям $(14240 \pm 280,14500 \pm 110,14500 \pm$ $\pm 140,14600 \pm 100$ л.н.) и, по-видимому, относятся к одной особи (рис. 4). Два других образца (один из группы “a” и один из группы "b”) являются частью скелета мамонтенка, найденного в 1999 г. на высоте 33.5 м над ур. м. и датированного как $14220 \pm 80$ л. н. (фрагмент черепа) и $14320 \pm$ \pm 60 л. н. (фрагмент ребра) (Sher et al., 2005). Значительно меньше датированных образцов относится к лошади -8 дат, из них одна неконечная, 2 даты сделаны по костям северного оленя и по одной дате по костям овцебыка и бизона.

Впервые не только на Быковском п-ове, но и во всем регионе моря Лаптевых, на обнажении Мамонтовый Хайата был найден фрагмент лучевой кости овцебыка голоценового возраста (3200 \pm \pm 80 л. н.) (рис. 4). Эта находка доказывает, что в позднем голоцене овцебыки жили в регионе дельты р. Лены (Kuznetsova et al., 2001). Ранее голоце-

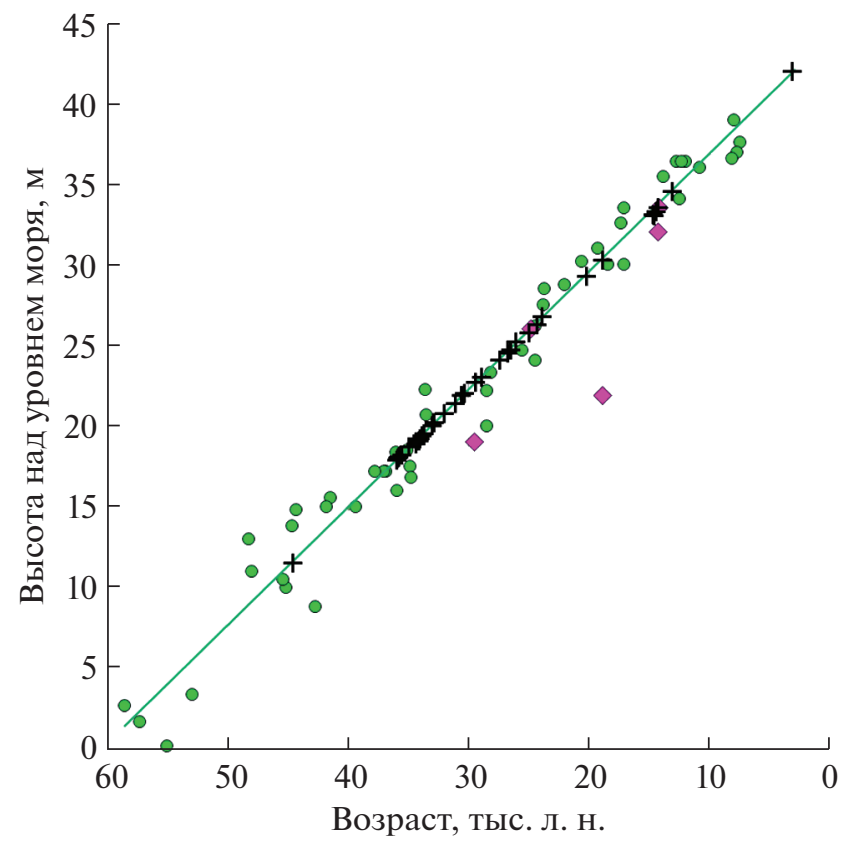

- Датировка по растительным остаткам

๑ Датировки по коллагену из костей, найденных in situ

+ Датировки по коллагену из костей, найденных

Рис. 3. Распределение радиоуглеродных датировок по растительным остаткам и костям млекопитающих, собранных на обнажении Мамонтовый Хайата и под ним. Прямая линия - линейный тренд, построенный по датировкам растительных остатков. Датировки по костям млекопитающих выставлены по линии тренда для установления их потенциальной высоты первичного залегания.

новые даты по овцебыкам были известны только с п-ова Таймыр (2920 $\pm 50 ; 2700 \pm 70$ л. н. (Сулержицкий, Романенко, 1997)) и $2900 \pm 60$ л. н. (Sher et al., 2005).

Продатированы 15 костей млекопитающих, собранных на берегу и отмели под обнажением, из них 4 даты оказались неконечные. Как обычно, преобладают даты по мамонту -8 дат, две из которых неконечные. Кроме этого, 4 даты принадлежат лошадям, 2 даты - овцебыкам, одна из которых неконечная, и одна неконечная дата относится к бизонам. Позднеголоценовая датировка (3180 \pm 100 л. н.) грудного позвонка овцебыка подтверждает наше предположение об обитании овцебыков на этой территории в позднеголоценовое время.

Мамонтовая терраса. Датировки по костному материалу с Мамонтовой террасы, в основном, имеют поздненеоплейстоценовый возраст (Kuznetsova et al., 1999), что подтверждает происхождение материала из таберальных образований.

С этого обнажения датировано 16 костей, 4 даты получены неконечные (табл. 2). Всего прода- 


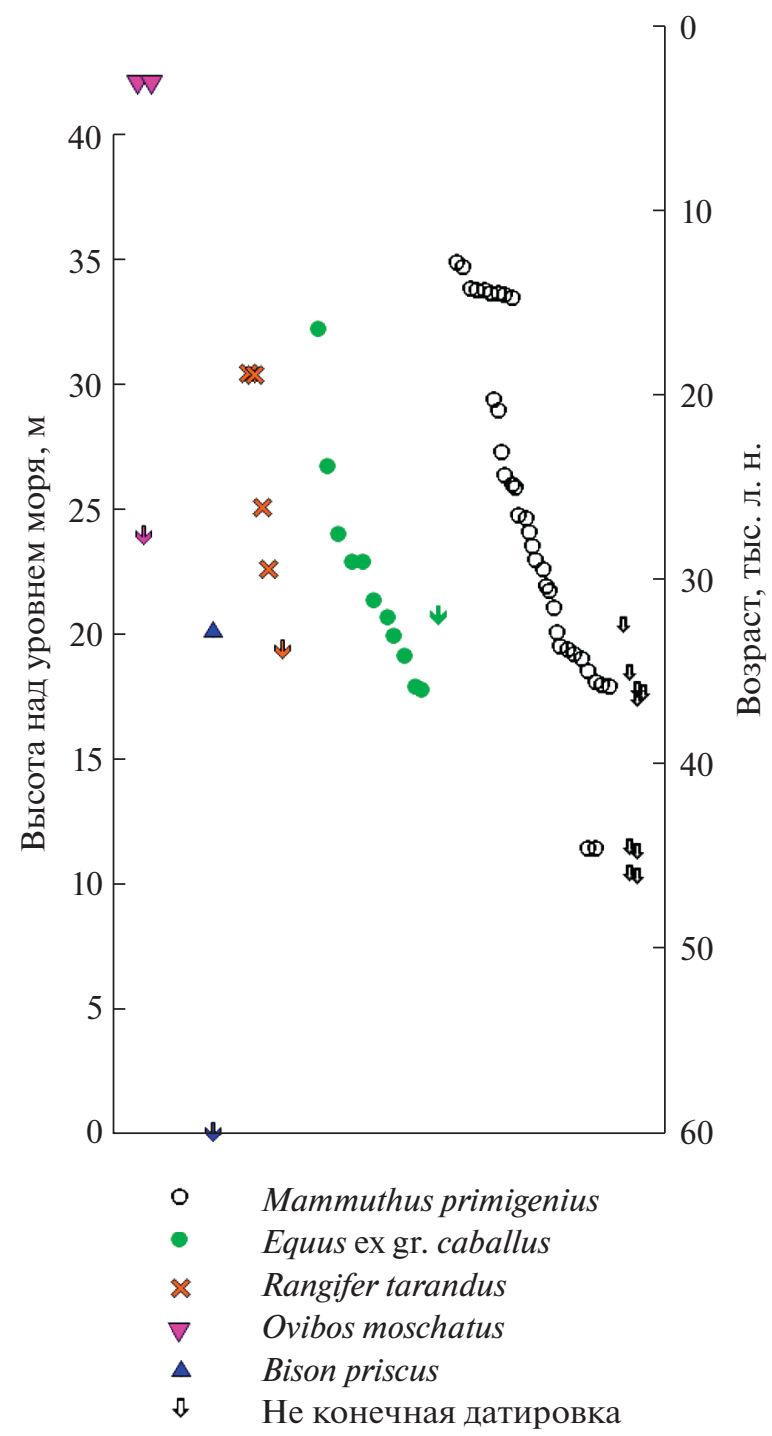

Рис. 4. Распределение радиоуглеродных датировок по костям млекопитающих, полученных авторами, по высотам обнажения Мамонтовый Хайата.

тированы кости четырех представителей мамонтовой фауны: мамонт - 6 дат, одна из которых неконечная, лошадь - 6 дат, две из которых неконечные, бизон - 2 даты, одна из которых неконечная, и пешерный лев - 2 даты. Несмотря на небольшое общее количество дат, они являются очень показательными.

Основная масса конечных дат с обнажения Мамонтовая терраса относится к интервалу от 36 до 23 тыс. л. н., т.е. интервалу с наибольшим количеством дат, выделенному по датировкам с обнажения Мамонтовый Хайата.

Голоценовая дата, полученная по фрагменту большой берцовой кости лошади $4610 \pm 40$ л. н., подтвердила ранее высказанное предположение (Лазарев, 1980) о существовании лошадей в голо- ценовое время на побережье Северного Ледовитого океана. После проведенных работ по изучению мамонтовой фауны в рамках проекта "Система моря Лаптевых" не возникает сомнений в обитании кабаллоидных лошадей во второй половине голоцена в арктических регионах Сибири (Kuznetsova et al., 2001).

Две даты по P. spelaea (28450 \pm 140 л. н. и $28550 \pm$ \pm 140 л. н.), полученные по клыку и правой ветви нижней челюсти (Stuart, Lister, 2011), вероятнее всего, относятся к одному животному. Это первые даты, полученные по пещерному льву с арктического побережья Восточной Сибири.

\section{Палеозоологическая характеристика и радиоуглеродные датировки костных остатков млекопитающих, найденных в других частях Быковского п-ова и на о-ве Муостах}

В 2001 г. в береговом обнажении, расположенном на юго-восток от обнажения Мамонтовый Хайата, в нижней части на ледяном склоне с байджерахами, был найден вытаявший фрагмент мумии молодой лосихи (Alces alces L. 1758) (Sher et al., 2002). Радиоуглеродное датирование шкуры и фрагмента кости конечности показало, что животное обитало на Быковском п-ове в раннем голоцене $-8080 \pm 120$ л. н. По споро-пыльцевым спектрам и данным по жукам, полученным по образцам с Мамонтовый Хайаты, около 8 тыс. лет назад на Быковском п-ове произрастало большое количество кустарников (кустарничковая тундра или лесотундра), что подтверждается и находками кустарников рядом с мумией лося. Это время начала голоценового оптимума, характеризующегося самым теплым и мокрым летом в течение последних 50 тыс. лет (Schirrmeister et al., 2002a). Северная граница ареала современных лосей проходит значительно южнее, по границе тундры и лесотундры. Однако летом лоси часто заходят в тундру по долинам рек, заросшим кустарником (Лабутин и др., 1985). По устным сообщениям сотрудников Усть-Ленского заповедника, трижды за 10 лет отмечалось появление лосей в южной части дельты р. Лены и южнее пос. Тикси. На северном побережье дельты и на Быковском п-ове лоси замечены не были.

С других обнажений и с берега восточной части Быковского п-ова собраны единичные кости млекопитающих. С берега на мысе Мамонт собрано 9 костей конечностей и их фрагментов четырех наиболее распространенных крупных млекопитающий мамонтовой фауны - мамонта, лошади, бизона и северного оленя. 7 костей собрано с байджерахов и берега озера Мамонт, 2 кости (кости конечностей $E$. ex gr. caballus, B. priscus) coбраны с берега за мысом Мамонта. На дальней косе собрано 12 костей и их фрагментов, они отличаются от всех рассмотренных ранее большей 
степенью окатанности и маленькими размерами, т.к. найдены далеко от берега. К этой группе костей относятся мелкие обломки костей конечностей мамонта, бизона, северного оленя, а также зайца и песца. Возможно, что кости северного оленя, зайца и песца относятся к современным представителям.

Две кости B. priscus с мыса Мамонта датированы, по одной из них получена самая древняя на настоящий момент датировка по костям млекопитающих из этого региона $-56700 \pm 3200$ л. н. (Shapiro et al., 2004). С озера Мамонт датирована нижняя челюсть мамонта и получена вполне ожидаемая дата - $23050 \pm 120$ л. н. (табл. 2).

Остров Муостах. Основываясь на данных по палеогеографии территории дельты р. Лены, о-ов Муостах следует рассматривать как часть Быковского п-ова, отделившуюся от него вследствие активного таяния ледового комплекса (Григорьев, 1993). Как и Быковский п-ов, о-в Муостах является остатком аккумулятивной равнины перед хребтом Хараулах. Основная часть острова сложена ледовым комплексом видимой мощностью 30 м от уреза воды. Он представлен песчаными и супесчаными отложениями, которые содержат большое количество органического материала, включают почвенные и торфяные горизонты, а также содержат значительное количество подземных льдов, включая повторно-жильные льды шириной до 5 м. Берега острова подвержены активной береговой термоабразии. Отложения ледового комплекса, обнажающиеся на о-ве Муостах, по данным радиоуглеродного датирования, имеют возраст от 46.8 тыс. л. н. до 19.6 тыс. л. н. (Schirrmeister et al., 2011).

Во время короткого посещения в 2002 г. на о-ве Муостах было собрано 7 костей, относящихся к M. primigenius, E. ex gr. caballus и B. priscus. Все кости собраны с берега, за исключением одного фрагмента кости млекопитающего, не определенного до вида. Этот фрагмент был отобран из осыпи с разреза на высоте 3-6 м над ур. м. (Shirrmeister et al., 2003). С острова продатированы две кости мамонта $-38420 \pm 400$ л. н. и $38200 \pm 500$ л. н. (табл. 2).

\section{ОБСУЖДЕНИЕ}

\section{Сравнение датировок по костям с обнажения Мамонтовый Хайата с датировками по растительным остаткам}

Обнажение Мамонтовый Хайата является одним из немногих обнажений в арктической Якутии, в котором, судя по датировкам растительных остатков, осадконакопление шло постоянно, без перерывов на протяжении почти 52.5 тыс. лет. Датировки растительных остатков из отложений Мамонтовый Хайаты охватывают интервал от
60 тыс. л. н. (58400 + 4960/-3040 л. н.) до 7.5 тыс. л. н. (7520 \pm 50 л. н.) (Schirrmeister et al., 2002). На фоне столь постоянного осадконакопления распределение костных датировок по разрезу не однородно (рис. 4).

Из 52 конечных дат, сделанных как по костям, собранным на обнажении, так и по костям, собранным на берегу и отмели под обнажением Мамонтовый Хайата, основная масса датировок располагается в интервале от 36 до 12.5 тыс. л. н., а их максимум приходится на период от 36 до 23 тыс. л. н. Две даты относятся к периоду 45.5-43.5 тыс. л. н. и две даты - к периоду около 3 тыс. л. н. (рис. 4).

В интервал от 36 до 23 тыс. л. н. попадают датировки мамонтов, лошадей, северных оленей и бизона. Скопление датировок в этом возрастном интервале можно объяснить двумя причинами. Во-первых, соотнеся датировки по растительным остаткам (Schirrmeister et al., 2002) и датировки по костным остаткам (рис. 3, 4), мы примерно восстановили интервал разреза, откуда происходит основная масса костей - это средняя и верхняя часть обнажения высотой от 17.5 до 27 м над ур. м. Как отмечалось ранее, на высоте от 10 до 15 м над ур. м. располагается горизонт торфяников, на основе которого формируется термотерраса (Siegert et al., 1999; Schirrmeister et al., 2002). При термоденудации разреза происходит вытаивание костного материала из отложений на различной высоте, его оплывание и концентрация на термотеррасе, иногда со вторичным вмерзанием. Возможно, что эта геоморфологическая особенность строения разреза Мамонтовый Хайаты является причиной концентрации датировок по костям от 36 до 23 тыс. л. н., т.к. на термотеррасе скапливаются кости из отложений, располагающихся выше

Вторая причина, объясняющая концентрацию датировок, это то, что период от 36 до 23 тыс. л. н. являлся наиболее благоприятным по своим климатическим условиям для жизни млекопитающих мамонтовой фауны за последние 45 тыс. лет. Наибольшее количество животных мамонтовой фауны, обитавших на территории сегодняшнего Быковского п-ова, приходится по палеоклиматической реконструкции Шера и других (Sher et al., 2005) на конец периода “теплой” тундростепи с сухим и теплым летом (48-34 тыс. л. н.) и на следовавший за ним (34-23.5 тыс. л. н.) период “холодной” тундростепи с сухим и теплым летом, которое было теплее, чем в настоящее время на данной территории, но холоднее, чем в предыдущую эПоху.

Интервал от 23 до 15 тыс. л. н. характеризуется значительно меньшим количеством датировок (рис. 4). Уменьшение количества датировок (всего 7 дат: мамонты, северные олени, лошади) (табл. 2) связано, естественно, с уменьшением количества костных остатков животных, собран- 
ных на обнажении. Во-первых, это объясняется уменьшением объема отложений, подвергающихся термоденудации на разрезе. Отложения, сформировавшиеся в период от 23 до 15 тыс. л. н., сохранились и обнажаются только в самой высокой центральной части обнажения Мамонтовый Хайаты на высоте от 27 до 33.5 м над ур. м. (рис. 4).

Во-вторых, палеоклиматические условия в интервале 23-15 тыс. л. н. были суровее, чем в более ранние периоды. Это “холодная” тундростепь с сухим и холодным летом (Sher et al., 2005). Однако даже в таких суровых условиях и мамонты, и копытные обитали на территории Быковского п-ова.

Увеличение количества датировок в период от 15 до 12.5 тыс. л. н. (рис. 4), даже с учетом того, что несколько датировок от одной особи были объединены, приходится на время "самой теплой" тундростепи с сухим и теплым летом (Sher et al., 2005). Однако пока не понятно, почему из этого временного интервала известны только даты по мамонтам, а дат по копытным нет. Такое распределение дат отмечается для всего региона моря Лаптевых (Sher et al., 2005). Если по мамонтам в интервал от 15 до 12.5 тыс. л. н. попадает 21 дата (Sher et al., 2005), то по копытным известна только одна дата по лошади - $14100 \pm 160$ л. н. (Сулержицкий, Романенко, 1997). По овцебыку близко к этому интервалу известны две даты с п-ова Таймыр: $15800 \pm 50$ л. н. (MacPhee et al., 2002) и $12150 \pm 40$ л. н. (Сулержицкий, Романенко, 1997). Вероятно, этот временной интервал можно охарактеризовать малым количеством или отсутствием копытных мамонтовой фауны, обитавших в рассматриваемом регионе. Условия окружающей среды были неблагоприятны для их обитания. Можно предположить, что во время “самой теплой” тундростепи уже началось постепенное заболачивание территории. Это является неблагоприятным фактором обитания для крупных копытных, что и привело к сокращению их количества.

Этому временно́му интервалу соответствуют породы, формирующие обнажение Мамонтовый Хайаты на высоте от 33.5 до 35 м над ур. м. Их объем, подвергающийся термоденудации, еще меньше даже по сравнению с предыдущим интервалом обнажения от 27 до 33.5 м над ур.м. Это, естественно, является причиной меньшего количества костных остатков, вытаивающих из породы (рис. 4).

Из верхних пяти метров обнажения находок костей нет. Это связано и с иными условиями осадконакопления - в это время уже не формировался ледовый комплекс, и с малой обнаженностью отложений возраста 12.5-7.5 тыс. л. Н., а также с вымиранием мамонтовой фауны в целом. В самом конце позднего неоплейстоцена и в начале голоцена количество крупных млекопитаю- щих на территории современного восточного побережья Быковского п-ова резко сократилось, но они полностью не исчезли, о чем свидетельствует находка мумии лосихи возрастом около 8 тыс. л. н. (Sher et al., 2002).

Две самые молодые даты по остаткам овцебыка (около 3 тыс. л. н.), найденные на Мамонтовый Хайате, происходят из делювиально-склоновых отложений поверхности едомы, которые сформировались во второй половине голоцена. Из этого же типа отложений на обнажении Мамонтовая терраса найдена кость лошади, датированная около $4610 \pm 40$ л. н.

Бросается в глаза полное отсутствие датировок в интервале от 43.5 до 36 тыс. л. н. (рис. 4). Оно не может объясняться только наличием термотеррасы на обнажении, к тому же древнее - около 44.5 тыс. л. н. все же есть две даты. Уровень термотеррасы не везде одинаков, и если она расположена на высоте 10 м над ур. м., можно было бы надеяться на находки костного материала из этого возрастного диапазона, однако их нет. Датировки по растительным остаткам в интервале 43.5-36 тыс. л. н. присутствуют в обычном количестве (рис. 3) (Schirrmeister et al., 2002). Вероятно, условия окружающей среды в период “теплой” тундростепи с сухим и теплым летом (Sher et al., 2005) были неблагоприятны для обитания крупных млекопитающих мамонтовой фауны на территории современного Быковского п-ова.

Нижняя часть разреза, хотя и находится над уровнем моря, слабо подвергается денудации и, в основном, закрыта термоделяпсивными образованиями из вышележащих оттаявших и перемещенных отложений. Кроме двух конечных дат по костям мамонта, около 44.5 тыс. л. н., что по растительным датировкам соответствует высоте около 11-12 м над ур. м. (рис. 3,4$)$, есть еще несколько неконечных датировок по костям мамонта и бизона (>44.000; >44.300; >45.500; >45.600; $>59.300$ ) (табл. 2). Они указывают на то, что датированные кости происходят из нижней части разреза, однако их сохранность, а также ограничения радиоуглеродного метода датирования не дают возможность получить конечные даты.

\section{ЗАКЛЮЧЕНИЕ}

Отложения ледового комплекса, развитые на Быковском п-ове и о-ве Муостах, в общих чертах имеют сходное мерзлотно-геологическое строение. Нижняя часть - это пылеватые супеси аллювиального происхождения. Они перекрываются горизонтом полигональных автохтонных торфяников, выше которого залегают делювиальнопролювиальные пылеватые суглинки. Максимальная мощность ледового комплекса - около 50-55 м в районе обнажения Мамонтовый Хайа- 
та. Все отложения имеют высокую льдистость и содержат мощные сингенетические повторножильные льды. Формирование отложений ледового комплекса Быковского п-ова и о-ва Муостах происходило в пределах поздненеоплейстоценовой аккумуляционной равнины. Отложения ледового комплекса перекрываются покровным горизонтом пылеватых суглинков мощностью 1-2 м раннеголоценового возраста, образовавшегося в результате площадной термопланации отложений ледового комплекса и увеличения мощности сезонно-талого слоя. Он имеет высокую льдистость, но не содержит ледяных жил.

Остатки представителей мамонтовой фауны являются важной характеристикой отложений ледового комплекса. Мамонты, лошади, северные олени, бизоны и овцебыки - наиболее многочисленны из крупных млекопитающих. Уникальная непрерывность осадконакопления поздненеоплейстоценовых отложений разреза Мамонтовый Хайата позволяет с большой степенью вероятности утверждать, что неоднородность распределения костного материала по высоте залегания в толще ледового комплекса связана с изменениями количества животных, обитавших на исследуемой территории. Это обусловлено изменениями палеоклиматических условий на протяжении позднего неоплейстоцена.

В интервале от 60 до 7.5 тыс. л. н. выделяется период максимально благоприятных условий обитания крупных млекопитающих мамонтовой фауны 36-23 тыс. л. н. Вопреки сложившемуся мнению (Sher et al., 2005; Schirrmeister, 2002а и др.), большое количество мамонтов и крупных копытных обитало на территории современного Быковского п-ова в период “холодной” тундростепи с сухим летом, которое было немного теплее современного (современная средняя температура воздуха в июле в районе пос. Тикси $+7^{\circ} \mathrm{C}$ (Sher et al., 2005)). В период с 23 до 15 тыс. л. н. в менее благоприятных условиях “холодной” тундростепи с сухим и холодным летом на изучаемой территории так же обитали и мамонты и копытные, но их было существенно меньше. Возможно, что большинство крупных представителей мамонтовой фауны в это время обитало в более южных районах Сибири.

Совершенно противоположная картина наблюдается в периоды “теплой” (48-34 тыс. л. н.) или “самой теплой” (15-11 тыс. л. н.) тундростепи. На изучаемой территории копытных не было или они обитали в очень небольших количествах (по ним нет датировок из этих временных интервалов). Лишь в конце периода "теплой” тундростепи 36-34 тыс. л. н. и перехода ее к “холодной” представители мамонтовой фауны в большом количестве заселили территорию современного Быковского п-ова.
В условиях “самой теплой” тундростепи, по имеющимся у нас данным, на территории современного Быковского п-ова из крупных млекопитающих мамонтовой фауны, в основном, обитали мамонты. Для копытных условия окружающей среды в период “самой теплой” тундростепи были некомфортными. Возможно, что в этот период начало происходить заболачивание почвы, что является крайне неблагоприятным для крупных копытных.

Находки костей позднеголоценовых овцебыков и лошадей на восточном побережье Быковского п-ова указывают на то, что эти копытные вернулись на свои прежние места обитания или их количество существенно увеличилось в позднем голоцене. Отсутствие копытных в раннеголоценовое время, по-видимому, связано с голоценовым климаическим оптимумом. В раннем голоцене территории современного Быковского п-ова была покрыта кустарниковой тундрой, а местами и лесотундрой. На это указывает большое количество остатков кустарников и даже деревьев, найденных в отложениях разреза Мамонтовая терраса, возраст которых 9.5-9 тыс. л. н. Ландшафты с кустарниковой тундрой и лесотундрой не являются благоприятными для обитания крупных копытных. На отсутствие остатков раннеголоценовых лошадей и овцебыков на Таймыре, а затем их возвращение в позднем голоцене, так же указывают в своей работе Сулержицкий и Романенко (1997).

Мы надеемся, что дальнейшее изучение местонахождений и расширение знаний о представителях мамонтовой фауны, обитавших на территории современной дельты р. Лены и на побережье моря Лаптевых, даст возможность более подробного восстановления изменений условий окружающей среды в позднем неоплейстоцене и голоцене в изучаемом регионе.

\section{БЛАГОДАРНОСТИ}

Мы благодарны всем участникам российско-германской экспедиции "Lena Delta" за помощь и поддержку при работе в полевых условиях. Благодарим коллег заведующего лабораторией стратиграфии четвертичного периода ГИН РАН А.С. Тесакова, старшего научного сотрудника той же лаборатории М.В. Сотникову, старшего научного сотрудника кафедры биогеографии географического факультета МГУ им. М.В. Ломоносова А.Н. Калякина и заведующего Палеонтологическим музеем, старшего научного сотрудника ПИН РАН А.А. Карху и за помощь в определении материала по грызунам, хищным млекопитающим и птицам, соответственно.

За финансовую поддержку исследований Т.В. Кузнецова благодарна стипендиальной программе лаборатории им. О.Ю. Шмидта (OSL Fellowship 2002-2009, 2015 programs). 


\section{СПИСОК ЛИТЕРАТУРЫ}

Бунге $A$., 1895. Описание путешествия к устью реки Лены 1881-1884 // Труды русской полярной станции на устье Лены. Ч. 1. Астрономические и магнитные наблюдения за 1882-1884 год. Под редакцией А.А. Тилло. Приложение. Санкт-Петербург: Русское географическое общество. $96 \mathrm{c.}$

Гейни, A.E., Гарутm В.E., 1964. Определение абсолютного возраста ископаемых остатков мамонта и шерстистого носорога из вечной мерзлоты Сибири при помощи радиоактивного углерода $\left(\mathrm{C}^{14}\right) / /$ Доклады АН СССР. Т. 154. № 6. С. 1367-1370.

Григорьев М.Н., 1993. Криоморфогенез устьевой области р. Лена. Якутск: Изд-во Ин-та мерзлотоведения CO PAH. $176 \mathrm{c}$.

Кузнецова Т.В., Стародубцева И.А., 2009. Мамонты и история геологического изучения побережья моря Лаптевых и Новосибирских островов // Система моря Лаптевых и прилегающих морей Арктики: современное состояние и история развития. Отв. ред. Кассенс Х., Лисицын А.П., Тиде Й., Полякова Е.И., Тимохов Л.А., Фролов И.Е. М.: Изд. МГУ. С. 481500.

Кузнецова Т.В., Тесаков А.С., 2003. Новые данные по плейстоценовой микротериофауне северо-восточного побережья моря Лаптевых (о-в Большой Ляховский и Быковский п-ов) // Естественная история российской восточной Арктики в плейстоцене и голоцене. М.: ГЕОС. 2003. С. 27-31.

Кузнецова Т.В., Ширрмейстер Л., Носкова Н.Г., 2004. Коллекции «Мамонтовой фауны» из района моря Лаптевых в музеях и институтах Российской Академии наук // Научно-практическая конференция “Проблемы региональной геологии, музейный ракурс”. Москва, 1-3 декабря 2004. Тезисы докладов. М.: Акрополь. С. 45-50.

Лабутин Ю.В., Перфильева В.Н., Ревин Ю.В. и др., 1985. Растительный и животный мир дельты реки Лена. Якутск: Якутское отделение Академии наук СССР. C. $123-124$.

Лазарев П.А., 1980. Антропогеновые лошади Якутии. М.: Наука. $190 \mathrm{c.}$

Cлагода E.A., 2004. Криолитогенные отложения приморской равнины моря Лаптевых: литология и микроморфология. Тюмень: Экспресс. 120 с.

Спижарский Т.Н., 1937. Геологический очерк ЛеноИндигирского района // Труды Арктического Института. Т. 87. С. 313-366.

Сулержицкий Л.Д., 1995. Характерные черты радиоуглеродной хронологии шерстистого мамонта (Mammuthus primigenius) в Сибири и на севере Восточной Европы // Труды Зоологического Института. Т. 263. С. 163-183.

Сулержицкий Л.Д., Романенко Ф.А., 1997. Возраст и распределение "Мамонтовой” фауны в Полярной Азии (согласно радиоуглеродным датам) // Криосфера Земли. Т. 1. № 4. С. 12-19.

Томирдиаро С.В., Арсланов К.А., Черненький Б.И., Тертычная Т.В., Прохорова Т.И., 1984. Новые данные о формировании лессово-ледовых толщ Северной Якутии и условия обитания Мамонтовой фауны в
Арктике в позднем плейстоцене // Доклады АН СССР. Т. 278. № 6. С. 1446-1449.

Черский И.Д., 1891. Описание коллекции послетретичных млекопитающих животных, собранных НовоСибирской экспедицией 1885-1886 гг. // Записки Императорской Академии Наук. Т. 65. Прил. 1. C. $1-706$.

Adams M., 1808. Some Account of a Journey to the FrozenSea, and of the Discovery of the Remains of a Mammoth // The Philadelphia Medical and Physical Journal. Part 1. V. 3. P. 120-137.

Averianov A., Kuznetsova T.V., Nikol'sky P., 2003. Pleistocene hares from the East Siberian Arctic (Lagomorpha, Leporidae) // Russian Journal of Theriology. V. 2. № 2. P. 24-32.

Kuznetsova T., Kuzmina S., Kunitsky V., Schirrmeister L., Sher A. 1999. The fauna of alas sequences in the Ice Complex area: the case of Mamontovy Bysagasa northwest exposure, Bykovsky Peninsula // Abstracts of Fifth Workshop on Russian-German Cooperation: Laptev Sea System 2000. St. Petersburg, Russia. November 2628, 1999. P. 49-50.

Kuznetsova T.V., Sulerzhitsky L.D., Siegert Ch., 2001. New data on the "Mammoth" fauna of the Laptev Shelf Land (Arctic Siberia) // Proceedings of the First International Congress "The World of Elephants". Rome, 16-20 October, 2001. P. 289-292.

MacPhee R.D.E., Tikhonov A.N., Mol D., de Marliave Ch., van der Plicht H., et al., 2002. Radiocarbon chronologies and extinction dynamics of the late Quaternary mammalian megafauna of the Taimyr Peninsula, Russian Federation // Journal of Archaeological Science. V. 29. № 2. P. 1017-1042.

Schirrmeister L., Kunitsky V., Grosse G., Kuznetsova T., Kuzmina S., Bolshianov D.Yu., 2001. Late Quaternary and recent environmental situation around the Olenyok Channel (western Lena Delta) and on Bykovsky Peninsula // Berichte zur Polarforschung. Reports on Polar and Marine Research. Russian-German Cooperation System Laptev Sea 2000. The expedition Lena 2000. V. 388. P. 85-135.

Schirrmeister L., Kunitsky V.V., Grosse G., Wetterich S., Meyer H., et al., 2011. Sedimentary characteristics and origin of the Late Pleistocene Ice Complex on North-East Siberian Arctic coastal lowlands and islands - a review // Quaternary International. V. 241. P. 3-25.

Schirrmeister L., Siegert C., Kunitzky V.V., Grootes P.M, Erlenkeuser H., 2002. Late Quaternary ice-rich permafrost sequences as a paleoenvironmental archive of the Laptev Sea Region in northern Siberia / Journal of Earth Science. V. 91. P. 154-167.

Schirrmeister L., Siegert C., Kuznetsova T., Kuzmina S., Andreev A.A., et al., 2002a. Paleoenvironmental and paleoclimatic records from permafrost deposits in the Arctic region of northern Siberia // Quaternary International. V. 89. P. 97-118.

Shapiro B., Drummond A.J., Rambau, A., Wilson M.C., Matheu, P., et al., 2004. Rise and fall of the Beringian steppe bison // Science. V. 306. P. 1561-1565.

Sher A., Gukov A., Sofronov Yu., Kuzmina S., Sulerzhitsky L., 2002. Moose and tall shrubs: new evidence on the Early Holocene climatic optimum in the Lena Delta // Cli- 
mate Drivers of the North. Kiel, Germany. May 2002. Abstracts. P. 100-101.

Sher A.V., Kuzmina S.A., Kuznetsova T.V., Sulerzhitsky L.D. 2005. New insights into the Weichselian environment and climate of the East-Siberian Arctic, derived from fossil insects, plants, and mammals // Quaternary Science Reviews. V. 24. P. 533-569.

Sher A., Kuzmina S., Lisitsyna O., Parmuzin I., Demyankov S., 2002. Paleoecological and permafrost studies of Ice Complex in the Laptev Sea area (Bykovsky Peninsula) // Berichte zur Polar- und Meeresforschung. Reports on Polar and Marine Research. Russian-German Cooperation System Laptev Sea 2000: The Expedition Lena 2001. V. 426. P. 94-107, 171-186.
Sher A., Parmuzin I., Bortsov A., 2000. lce Complex on Bykovsky Peninsula // Berichte zur Polar- und Meeresforschung. Reports on Polar Research. Russian-German Cooperation System Laptev Sea 2000. The expedition Lena 1999. V. 354. P. 169-182.

Siegert C., Schirrmeister L., Kunitsky V.V., Dereviagin A., Krbetschek M., et al., 1999. Paleoclimate signals in icerich permafrost // Berichte zur Polar- und Meeresforschung. Reports on Polar Research. Russian-German Cooperation System Laptev Sea 2000. The Lena Delta 1998 expedition. V. 315. P. 145-259.

Stuart A.J., Lister A.M., 2011. Extinction chronology of the cave lion Panthera spelaea // Quaternary Science Reviews. V. 30. P. 2329-2340.

\title{
PALAEOZOOLOGICAL CHARACTERISTICS OF THE LATE NEOPLEISTOCENE-HOLOCENE DEPOSITS OF BYKOVSKY PENINSULA, NORTHERN YAKUTIA
}

\author{
T. V. Kuznetsova ${ }^{1,2, *}$, V. E. Tumskoy ${ }^{1,3, * *}$, L. Schirrmeister ${ }^{4, * * *}$, S. Wetterich, ${ }^{4 * * *}$ \\ ${ }^{1}$ Faculty of Geology, M.V. Lomonosov Moscow State University, Moscow 119991, Russia \\ ${ }^{2}$ Kazan Federal University, Kazan 420008, Russia \\ ${ }^{3}$ Institute of Geography, Russian Akademy of Sciences, Moscow 119017, Russia \\ ${ }^{4}$ Alfred Wegener Institute, Helmholtz Center for Polar and Marine Research, Potsdam 14473, Germany \\ *e-mail: tatkuz2012@mail.ru \\ **e-mail:vtumskoy@gmail.com \\ ***e-mail: lutz.schirrmeister@awi.de \\ ****e-mail: sebastian.wetterich@awi.de
}

\begin{abstract}
The present study characterizes palaeozoological findings from the late Pleistocene and Holocene permafrost deposits of the Bykovsky Peninsula. The study proposes a method to differentiate fossil bone samples by the location of their finding and by the accuracy of their relation to a certain depositional horizon. A total of 90 radiocarbon dates of bone material from large mammals has been analyzed. The distribution of bone material along the sedimentary permafrost profile is not uniform. During the last 60.000 years, two periods of environmental conditions favourable for representatives of mammoth fauna are distinguished. "Cold" tundra-steppe environments with either dry and warm or cold summer conditions provided the most favourable settings for the existence of mammoths and hoofed mammals over the territory of the modern Bykovsky Peninsula.
\end{abstract}

Keywords: Mammoth fauna, Bykovsky Peninsula, radiocarbon dates, Neopleistocene, Holocene, palaeoenvironmental conditions, "cold" tundra-steppe 